Research Article

\title{
Seismic Response Analysis of Fully Base-Isolated Adjacent Buildings with Segregated Foundations
}

\author{
Khaled Ghaedi $(\mathbb{D}$, Zainah Ibrahim $(\mathbb{D}$, Mohammed Jameel $(\mathbb{D}$, Ahad Javanmardi, and \\ Hamed Khatibi \\ Department of Civil Engineering, University of Malaya, 50603 Kuala Lumpur, Malaysia \\ Correspondence should be addressed to Khaled Ghaedi; khaledqhaedi@yahoo.com and Zainah Ibrahim; zainah@um.edu.my
}

Received 27 August 2017; Accepted 26 November 2017; Published 12 March 2018

Academic Editor: Chiara Bedon

Copyright (c) 2018 Khaled Ghaedi et al. This is an open access article distributed under the Creative Commons Attribution License, which permits unrestricted use, distribution, and reproduction in any medium, provided the original work is properly cited.

\begin{abstract}
In populous cities, construction of multistorey buildings close to each other due to space limitation and increased land cost is a dire need. Such construction methods arise several problems during earthquake excitation. The aim of this study is to investigate the bidirectional seismic responses of fully base-isolated (FBI) adjacent buildings having different heights and segregated foundations. Therefore, two scenarios, namely, (a) investigation of the responses of FBI adjacent buildings compared to those with fixed base (FFB) and (b) the effects of separation distance on FBI adjacent buildings, were studied. Based on these investigations, the results showed that isolation system significantly enhances the overall responses of the BI buildings. Spectacularly, the base isolation system was further efficient to decrease displacement rather than the acceleration. In addition, increase of the seismic gap changed the acceleration, pounding, base shear, base moment, and storey drift, as well as the force-deformation performance of the isolators. Therefore, it seems a need to focus on the effect of the separation distances for the design of base isolators for FBI adjacent buildings in future works.
\end{abstract}

\section{Introduction}

Adjacent buildings are constructed without any structural link connected to surrounding buildings. However, in few cases, they are rarely connected at the foundation level. As a matter of fact, engineers have taken serious concerns about structural damages caused by devastating earthquakes [1-3]. Therefore, the structural pounding phenomenon will usually occur in adjacent buildings during earthquake excitations [4]. Consequently, the buildings with inadequate seismic gap suffer from damages due to the pounding force. Mexico City, 1985, and Northern California, 1989, are good examples to signify the importance of seismic gap between adjacent buildings. It is good enough to flashback both events where pounding effect has been seen by 132 demolished adjacent buildings in the Mexico City and 200 collapsed buildings in Northern California $[5,6]$. In this regard, many researchers have studied the structural responses of either the baseisolated (BI) building in adjacent with a conventional fixed supported building [7-9], FFB adjacent buildings, or adjacent building equipped with other dissipative devices $[6,10-18]$.

Structural responses of adjacent buildings have been investigated by means of nonlinear techniques which demonstrated that collapse of structures has a significant influence on the performance of light and flexibility of buildings mainly in the pounding direction [11, 19-22]. Penzien [23] used the complete quadratic mode combination (CQC) approach, whilst Kasai et al. [24] used the spectral difference (SPD) method to calculate the required gap between two FB adjacent buildings. Both techniques were able to predict the structural responses concerning building vibration. Moreover, the square root of the sum of the squares (SRSS) approach has been governed by the international buildings codes (IBC), and consequently, the required distances between buildings were provided [25]. Shrestha [26] offered a minimum required gap for buildings to prevent pounding by means of double difference combination (DDC) and SRSS techniques. The obtained results exhibited that the DDC method assessed the required 
separation gap to hold pounding up. Furthermore, structural responses of FFB adjacent buildings have been numerically analyzed [26, 27]. Khatiwada et al. [28] proposed the Hunt-Crossley model. The precise calculation of damping constant was presented in that model. The efficiency of Hunt-Crossley model in linear and nonlinear analysis for pounding simulation of concrete structures was compared with nonlinear viscoelastic, linear viscoelastic, and modified linear viscoelastic models. The nonlinear Hunt-Crossley model was capable to predict the contact force between FB adjacent buildings.

From the literature review, it was found that the seismic responses of FBI adjacent buildings have not been studied thoroughly. In this paper, an attempt was thoroughly made by dividing the scenarios into two cases comprising (i) investigate the seismic response characteristics of FBI adjacent building comparing to FFB buildings (Scenario 1) and (ii) investigate the gap size effect on seismic pounding of FBI adjacent buildings (Scenario 2) having different heights. For this aim, lead rubber bearings (LRB) were designed based on the NEHRP provisions [29]. Afterwards, a comparative analysis of two FFB and BI adjacent buildings under bidirectional seismic excitations was carried out.

\section{Methodology}

2.1. Nonlinear Dynamic Analysis. In the present study, nonlinear dynamic analysis was done using a typical bidirectional seismic recorded and a finite element (FE) analysis package. That is, SAP2000 was selected as an appropriate tool for aiding the purpose. The main equations of motion were taken deliberating equilibrium of forces at each DOF. The motion equations for superstructure and base isolation were written as

$$
[M]\left\{\ddot{y}_{b}+\dot{y}\right\}+[C]\{\dot{y}\}+[K]\{y\}=-[M]\left[T_{g}\right]\left[\ddot{y}_{g}\right],
$$

in which $[M]$ is the mass matrix, $[C]$ and $[K]$ are damping and stiffness matrix of the superstructure, respectively, and $\{y\}$ is the superstructure displacement. Displacement and acceleration corresponding to the ground are nominated by $\left\{y_{b}\right\}$ and $\left\{\ddot{y}_{g}\right\}$. The earthquake effect coefficient matrix is given by $\left[T_{g}\right]$.

All nonlinearities are only restricted to the elements of the base isolator. In the above dynamic equilibrium equation, the base isolator and superstructure are considered as nonlinear and elastic, respectively. Therefore, (1) is written as

$$
M \ddot{y}(t)+C \dot{y}(t)+K_{L} y(t)+r_{N}(t)=r(t),
$$

where $K_{L}$ is the stiffness matrix for superstructure as the linear elastic and $r_{N}$ is the force vectors due to nonlinear degrees of freedom related to isolator elements. The displacement, velocity, and acceleration corresponding to ground is determined by $y, \dot{y}$, and $\ddot{y}$, respectively; and the vector of imposed loads is defined by $r$. At nonlinear DOF, the effective stiffness is arbitrary, but it changes between zero and the utmost stiffness of that DOF. The equation of equilibrium could be rewritten as

$$
\begin{gathered}
{[M][\ddot{y}(t)]+[C][\dot{y}(t)]+\left[K_{L}\right][y(t)]+r_{N}(t)} \\
=r(t)-\left[r_{N}(t)-K_{N} y(t)\right],
\end{gathered}
$$

in which

$$
K=K_{L}+K_{N}
$$

where $K_{N}$ is the stiffness matrix for all nonlinear DOFs.

2.2. Gap Elements. The gap distance between the buildings was represented by the link element in SAP2000. It is remarkable that the gap (link) element is active only in a compression state. The function of the link element (gap element) is to transfer pounding force through itself only at the moment of the impact of buildings. The force-deformation correlation in nonlinearity form was expressed as follows:

$$
f= \begin{cases}k(d-\text { open }), & \text { if } d-\text { open }<0 \\ 0, & \text { otherwise }\end{cases}
$$

in which $k$ is the constant of spring, $d$ represents the displacement, and the initial gap opening (has to be zero or positive) is defined by open. For gap element in nonlinear analysis cases, its stiffness was defined as one to two orders stiffer than surrounding columns and beams in each level. The gap element stiffness was selected to be $10^{2}$ times larger than the stiffness of adjacent attached element. Hence, in this study, the stiffness of the gap elements was determined as

$$
K=\left(\frac{E A}{L}\right) \times 100 \text {, }
$$

$K=\frac{\text { Young's modulus of concrete } \times \text { contact surface area }}{\text { element length of contact surface }} \times 100$,

in which $A$ is the cross-sectional area of the element, $E$ is Young's modulus of the element, and $L$ is the element length in perpendicular direction to the contact surface. Furthermore, dissipating energy during collision can be determined by damping. The linear effective stiffness effect and damping were included in the gap element to achieve favourable contact behaviour.

2.3. Nonlinear Time History Analysis. The finite element software SAP2000 was implemented to investigate the response of adjacent buildings under different seismic loads by modelling two adjacent ordinary moment-resisting concrete frame (OMRCF) buildings considering FFB adjacent buildings and FBI adjacent buildings subjected to bidirectional earthquake excitations. Nonlinear dynamic time history analysis was carried out through bilateral seismic recorded of Cape (PGA $2.85 \mathrm{~m} / \mathrm{s}^{2}$ ), Los Angeles Century City, LACCNorth (PGA $3.85 \mathrm{~m} / \mathrm{s}^{2}$ ), Santa Monica (PGA $1.20 \mathrm{~m} / \mathrm{s}^{2}$ ), and El-Centro (PGA $3.20 \mathrm{~m} / \mathrm{s}^{2}$ ), as shown in Figure 1 .

Fast nonlinear analysis procedure proposed by Wilson has been weighed to solve the equilibrium equations [30]. The approach was exceedingly effective for structural systems that are initially linear elastic [2]. In the present study, material 


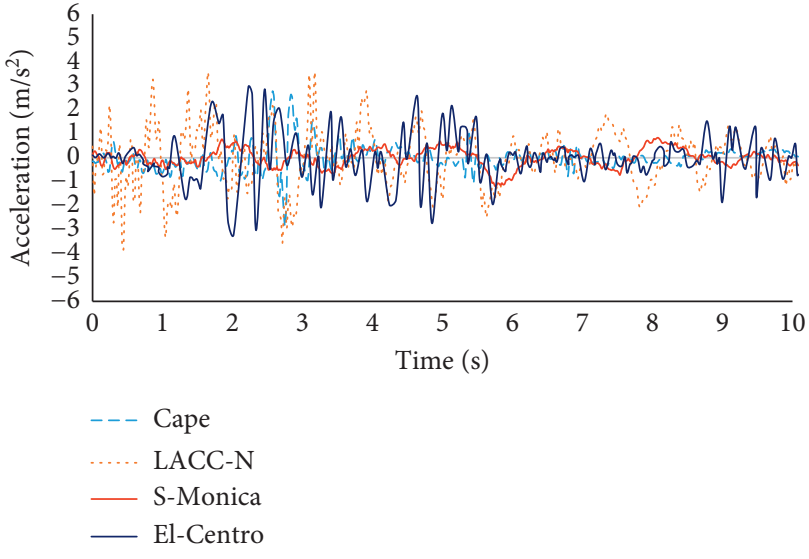

(a)

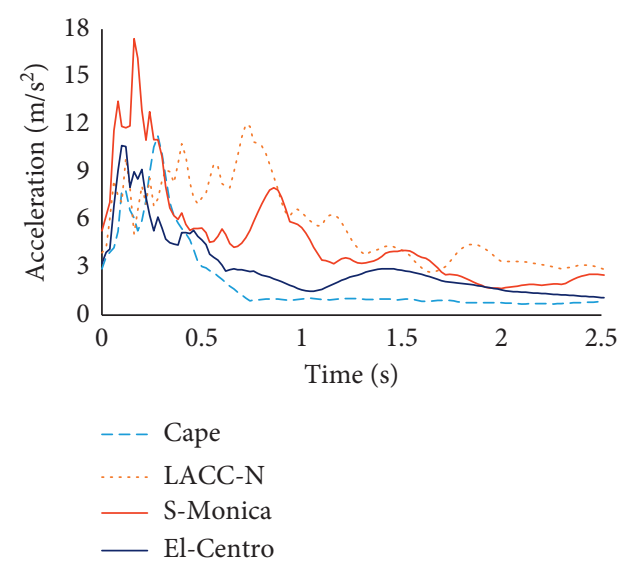

(b)

Figure 1: (a) Time histories and (b) spectral accelerations (5\% damping) of the applied earthquakes.

and link nonlinearities were also considered and direct integration was performed by the alpha method. All nonlinearities were restricted to the link (gap) elements. The detailed time history loading was imposed quasistatically through high damping. The fast nonlinear analysis method deliberates a ramp-form time history which rises in a linear trend from zero to one over a time period. Thus, the nonlinear equations were iteratively solved in every time step. Eventually, the iterations were accomplished until the result converges.

2.4. Base Isolator Design. Base isolator (herein LRB) device is shaped by placing a lead plug into a prepared orifice in the scant damping elastomeric bearing. The lead plug is deformed in shear due to enforcing of steel plates. LRB performance is preserved during repetition of severe ground motions with good reliability and durability. LRB generates the required damping and sophisticated initial stiffness. The LRB behaviour is affected by the horizontal elastomer stiffness, horizontal lead plug stiffness, and the yield strength of the lead plug.

The LRB isolator was designed as suggested by Kelly [31], Kelly et al. [32], and Naeim [33]. In this study, ISODNG09 (a computer code) has been made to design the isolator iteratively. The dimensions, total seismic weight, number of bearings layers, and their thickness were taken into account as the initial input. The parameters such as high initial stiffness, post-elastic stiffness, yield strength, effective damping, and post-yield stiffness ratio were calculated by means of the aforesaid code. The parameters were then assigned into SAP2000 software package. The bearings were connected at the bottom of the columns. In general, a lead core with $60 \mathrm{~mm}$ diameter and two $25 \mathrm{~mm}$ thick steel plates were used to attach both sides of the bearing. The IRHD (International Rubber Hardness Degrees) 50 was used for rubber material with shear modulus, Young's modulus, modified factor $(k)$, maximum shear strain $\left(\gamma_{\max }\right)$, and ultimate elongation of $0.64 \mathrm{MPa}, 2.2 \mathrm{MPa}, 0.73,50 \%$, and $650 \%$, respectively. Stiffness of nonlinear unloading was set to $10.57 \mathrm{kN} / \mathrm{mm}$, whereas the yield strength was $249.25 \mathrm{kN}$. The earthquake forces on the bearing taken from the

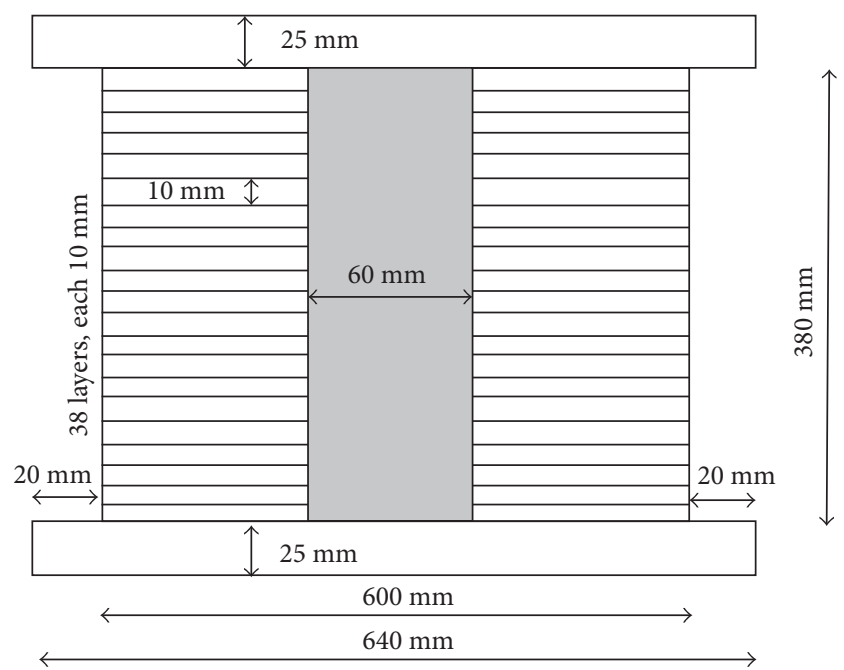

FIgURE 2: LRB details used in this study.

dynamic analysis of BI building were utilized to control the roll-out state of the base isolators. The designed height and diameter of the steel shim plates and rubbers were $380 \mathrm{~mm}$ and $600 \mathrm{~mm}$, respectively. Figure 2 demonstrates the LRB details used in the present study. The importance coefficient and response modification factor of isolated buildings were taken as $I=1.0$ and $R I=2.0$, respectively [31]. Configuration of damping system was analyzed for $10 \mathrm{~s}$ durational earthquake. The used time step for numerical solution was selected as $0.002 \mathrm{~s}$. The flowchart procedure for the design of isolators is illustrated in Figure 3.

2.5. Static Analysis. Analysis of linear static, the easiest of all, was carried out as the lowest level of complication. Seismic lateral force was defined by taking the $R$ and $Z$ factors, soil profile, importance factor, etc. Equations for earthquake analysis has been derived from Building and Housing Research Center (BHRC) of Iran [34]. The summation of the horizontal earthquake loads or the minimum base shear in each direction was expressed from 


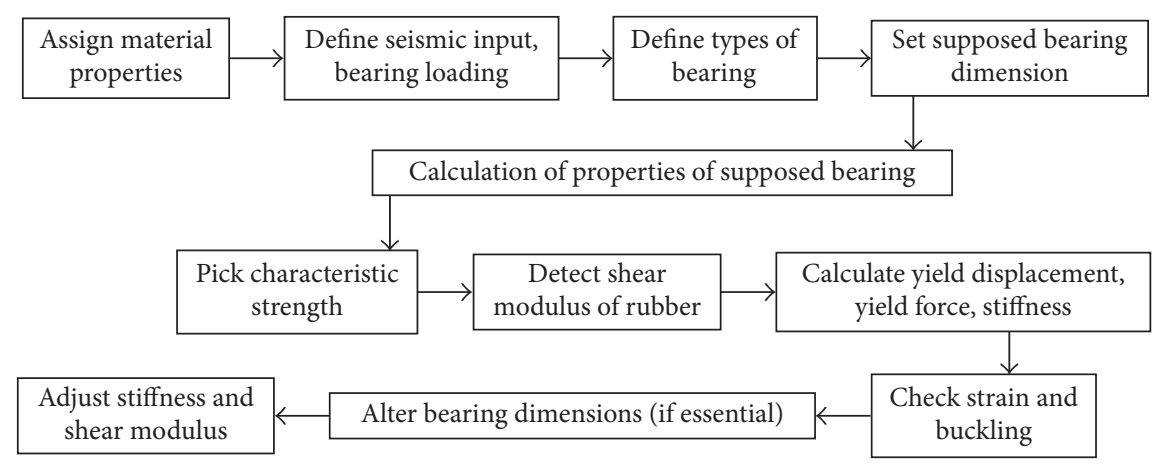

Calculation of seismic performance for maximum credible earthquake (MCE) and design base earthquake (DBE)

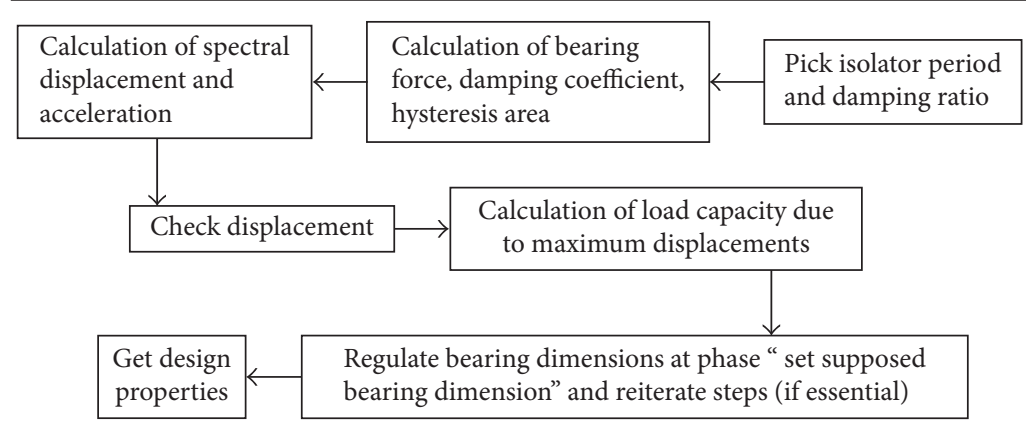

Figure 3: Typical design procedure of base isolators.

$$
V=C W
$$

in which $V$ is the shear force in the base level. The base level is determined as the level where the building does not have any movement with respect to the base ground during a seismic excitation, $W$ is the total weight of the structure, that is, the total dead load and a percentage of other loads, and $C$ is the seismic coefficient which was obtained from the following equation:

$$
C=\frac{A B I}{R}
$$

where $A$ is the design base acceleration $(g)$ and $B$ is the building response coefficient taken from the design response spectrum which was specified based on the below equation:

$$
B=2\left(\frac{T}{T_{0}}\right)^{2 / 3} \text {, }
$$

in which $T$ is the fundamental natural period and $T_{0}$ was specified based on the soil classification and for this study was defined as 0.3 for soil type $I$. $I$ is the importance factor, and $R$ is the building behaviour coefficient.

According to the BHRC, the design base shear must not be less than $V=0.1 A I W$ and the $C$ value must be greater than $10 \%$ of the $A$.

2.6. Required Lateral Force for Superstructures. To calculate the required lateral force for superstructures, we need to compute the minimum and then the maximum effective stiffness of the base isolators. In this regard, the equations are calculated as follows:

$$
\begin{gathered}
K_{D \min }=\frac{4 \pi^{2}}{g}\left(\frac{W}{T_{D}^{2}}\right), \\
K_{D \max }=(1.3)\left(K_{D \min }\right),
\end{gathered}
$$

in which the ground acceleration $(g)$, weight of the structure $(W)$, and the effective period $\left(T_{D}\right)$ are $9.81 \mathrm{~m} / \mathrm{s}^{2}, 3405198 \mathrm{~kg}$, and 3 seconds, respectively. Substituting these values in (10) gives the minimum and maximum effective stiffness, i.e., $15210.73 \mathrm{kN} / \mathrm{m}$ and $19773.95 \mathrm{kN} / \mathrm{m}$, respectively. Therefore, the required lateral force for superstructures, $V_{s}$, can be computed as below:

$$
V_{s}=\frac{V_{b}}{R_{I}}
$$

in which $V_{b}$ is the required lateral force for the isolation system. $R_{I}=(3 / 8) R$ which is the numerical coefficient regarding the type of lateral force resisting system above the base isolation system as given in Table 13.3.4.2 of NEHRP provision for seismically isolated structures. $R$ is the response modification coefficient as given in Table 5.2.2 of that provision and it is taken as 3 in this study. Hence, $R_{I}$ goes to be 1.125 . The above expression sets $V_{s}$ for $2590.878 \mathrm{kN}$.

2.7. Numerical Study. In this study, two adjacent buildings having different heights (4- and 8-storey buildings) were considered for the evaluation of structural pounding. The plan and elevation views of the buildings are shown in Figure 4. The place of seismic gaps $(30 \mathrm{~mm})$ for both the FFB and FBI adjacent buildings is illustrated in Figure 5. 


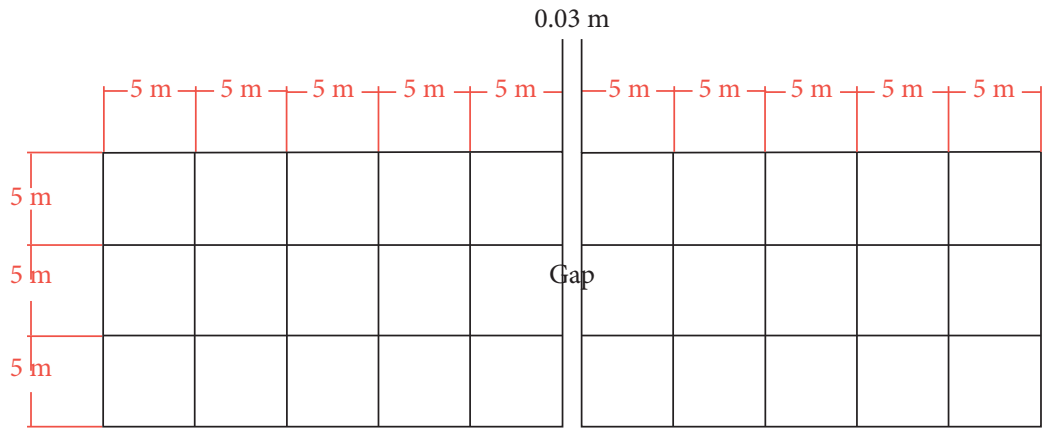

(a)

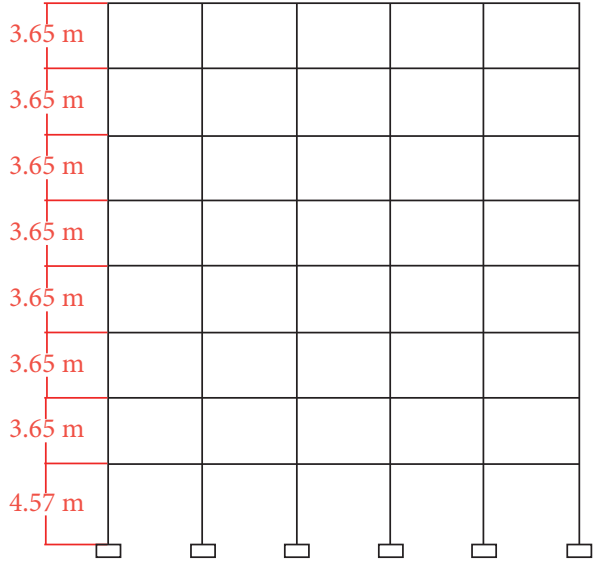

(b)

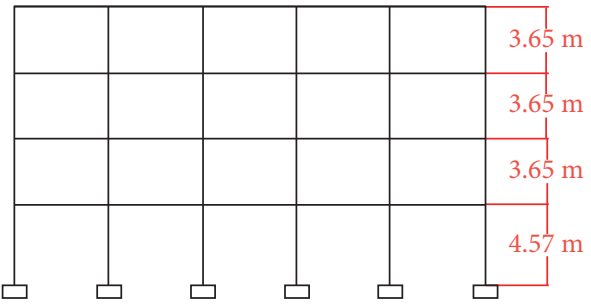

(c)

FIGURE 4: Plan and elevation views of buildings having segregated foundations. (a) Plan view; (b) 8-storey-level elevation view; (c) 4-storeylevel elevation view.

As Figure 4 shows, the total height of the 8-storey and 4-storey OMRCF buildings is $30.12 \mathrm{~m}$ and $15.52 \mathrm{~m}$, respectively. The frame section of columns and beams detailing for floor levels is described in Table 1. The gap elements between adjacent buildings were located at 4 joints (Figures 5(a) and 5(b)). Young's modulus and shear modulus of concrete were taken as $E=2.168 \times 10^{7} \mathrm{kN} / \mathrm{m}^{2}$ and $G=0.834 \times 10^{7} \mathrm{kN} / \mathrm{m}^{2}$, respectively.

\section{Results and Discussions}

The comparative results of the present study are divided into two parts, in which each part provides a comprehensive study on the objective:

(1) Responses of FBI adjacent buildings compared to the FFB adjacent buildings (Scenario 1).

(2) Gap size influence on the responses of the FBI adjacent buildings (Scenario 2).

\subsection{Seismic Responses of Fully BI Adjacent Buildings (Scenario 1)}

3.1.1. Free Vibration Analysis. It has ascertained that the input frequency generates the pounding force. In other words, the pounding force is a function of the frequency $[35,36]$. Moreover, the modes with large impressive masses are normally a substantial contributor to the response of the structures $[37,38]$. Table 2 presents the natural frequency of the FFB and FBI adjacent buildings considering the most participated mass ratio for the four effective modes in the longitudinal (pounding) direction. It can be seen from the table that the governor modes were changed from $1,4,7$, and 11 in the FFB system to $1,3,7$, and 10 in the FBI system. Furthermore, by comparing the common modes (1st and 7 th), it can be concluded that the base isolation system decreases the structure stiffness, therefore reducing the natural frequency. In such a circumstance, the superstructure part, as a rigid unit, will react to earthquake vibrations in lieu of resonating with imposed vibration. The obtained results from Table 2 confirmed that the isolation system reduced the natural frequency of the buildings by $28 \%-43 \%$ for the governor modes. It is obvious that, by decreasing the natural frequency, the time period will be lengthened which results to have a smooth vibration. Also, from the participating mass ratio analysis, it can be observed that the mass participation for the FBI buildings is greater that the FFB buildings in the first mode of vibration with a time delay.

For better understanding, the first modal vibration of the buildings for both FFB and FBI adjacent buildings is illustrated in Figure 6. In FFB condition, the adjacent buildings experienced a contact in the first mode. On the contrary, in the FBI condition, the taller building deflected 


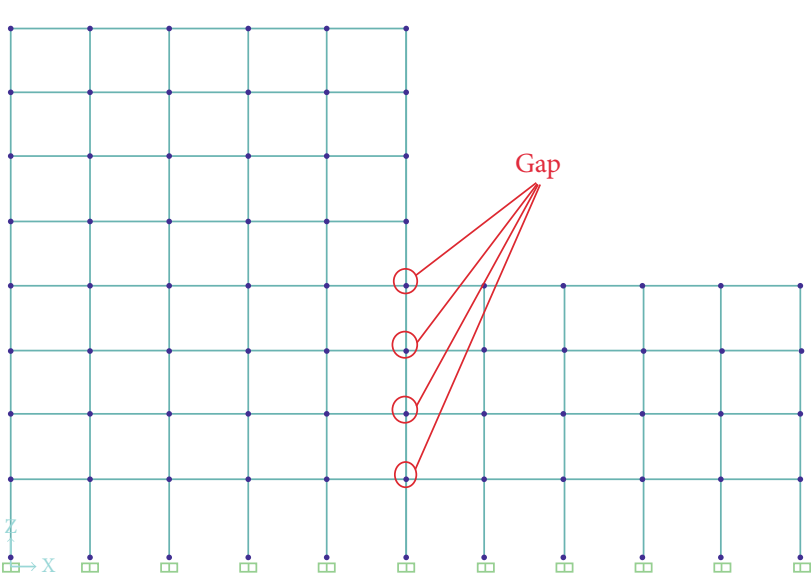

(a)

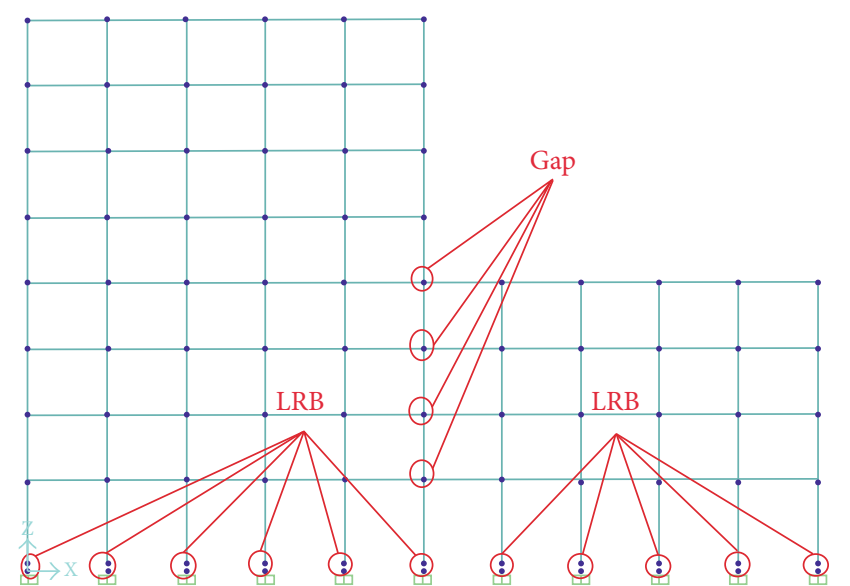

(b)

FIgURE 5: Location of gap elements and LRB devices in FFB and FBI buildings. (a) FFB adjacent buildings. (b) FBI adjacent buildings.

TABLE 1: Structural members of OMRCF adjacent buildings.

\begin{tabular}{lccccc}
\hline Column section & Short building & Tall building & Beam section & Short building & Tall building \\
\hline $55 \times 55$ & 1 & 1 & $40 \times 60$ & 2 & 2 \\
$50 \times 50$ & 2 & 2 & $40 \times 50$ & - & 4 \\
$45 \times 45$ & 1 & 2 & $30 \times 40$ & - & 3 \\
$40 \times 40$ & - & 3 & - & - \\
\hline
\end{tabular}

TABLE 2: Natural frequency of FFB and FBI systems considering the governor modes.

\begin{tabular}{|c|c|c|c|c|c|c|c|}
\hline \multirow{2}{*}{ Mode } & \multicolumn{3}{|c|}{$\mathrm{FB}$} & \multirow{2}{*}{ Mode } & \multicolumn{3}{|c|}{$\mathrm{BI}$} \\
\hline & $T(\mathrm{~s})$ & $\omega(\mathrm{Hz})$ & Mass part. ratio & & $T(\mathrm{~s})$ & $\omega(\mathrm{Hz})$ & Mass part. ratio \\
\hline 1 & 2.000 & 0.500 & 0.470 & 1 & 3.524 & 0.284 & 0.628 \\
\hline 4 & 0.962 & 1.039 & 0.301 & 3 & 2.435 & 0.411 & 0.357 \\
\hline 7 & 0.795 & 1.258 & 0.100 & 7 & 1.110 & 0.900 & 0.012 \\
\hline 11 & 0.440 & 2.271 & 0.043 & 10 & 0.558 & 1.791 & 0.001 \\
\hline
\end{tabular}

toward the left direction because of the effect of the base isolation system.

3.1.2. Displacement Response. The envelope displacement values for each floor level of the taller FB and BI buildings subjected to applied earthquakes are presented in Figure 7. As shown in the figure, the maximum displacements occurred at the top level (8th floor level) and the maximum displacements of the buildings in both positive and negative directions are shown for both FB and BI adjacent buildings. However, the top level displacements of the FBI buildings were generally greater than the FFB building, but by considering the base displacements for both systems, the relative displacement can be calculated. It can be seen from the figure that the relative displacement of the FBI building in both positive and negative directions was smaller than the relative displacement of the FFB building. To clarify the statement, the below expression is written for the system considering El-Centro motions:

Positive relative displacement of the FBI building: $21.2 \mathrm{~cm}-10 \mathrm{~cm}=11.2 \mathrm{~cm}<12 \mathrm{~cm}$ for the FFB building
(6.7\% reduction). Negative relative displacement of the FBI building: $(-18.1)-(-11.4) \mathrm{cm}=-6.7 \mathrm{~cm}<-12.1$ for the FFB building ( $44.7 \%$ reduction).

Furthermore, the distortion of FFB building under applied motions is not desirable such that the building deformations are not controlled unlike the FBI building which has a smooth deformation under the earthquakes as illustrated in the figure. Overall, taking an average calculation for the relative displacement of the buildings under different applied motions shows that the BI system is capable to reduce displacement responses up to $46 \%$ in the pounding (longitudinal) direction. The values are indicated in Table 3.

For a shorter building, it can be seen from Figure 8 that the relative displacement responses of the FBI building is less than the FFB building. The displacement values of the pounding floor (4th floor level) are illustrated in the figure for both the FFB and FBI buildings in both positive and negative directions. Similar to the taller building and with subtraction of the top displacement from the base displacement, the relative displacement can be computed. 


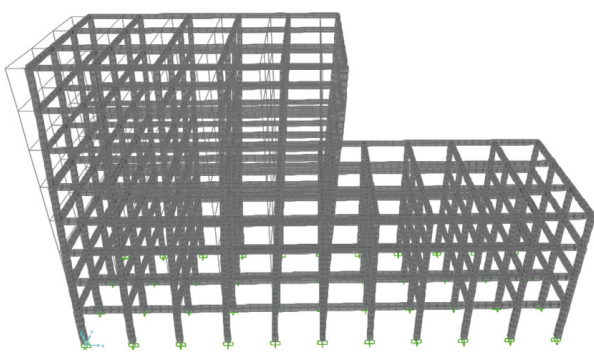

(a)

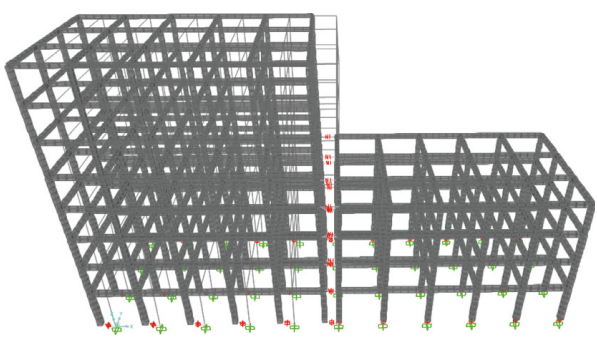

(b)

FIGURE 6: First modal response of the adjacent structures. (a) FFB adjacent buildings. (b) FBI adjacent buildings.

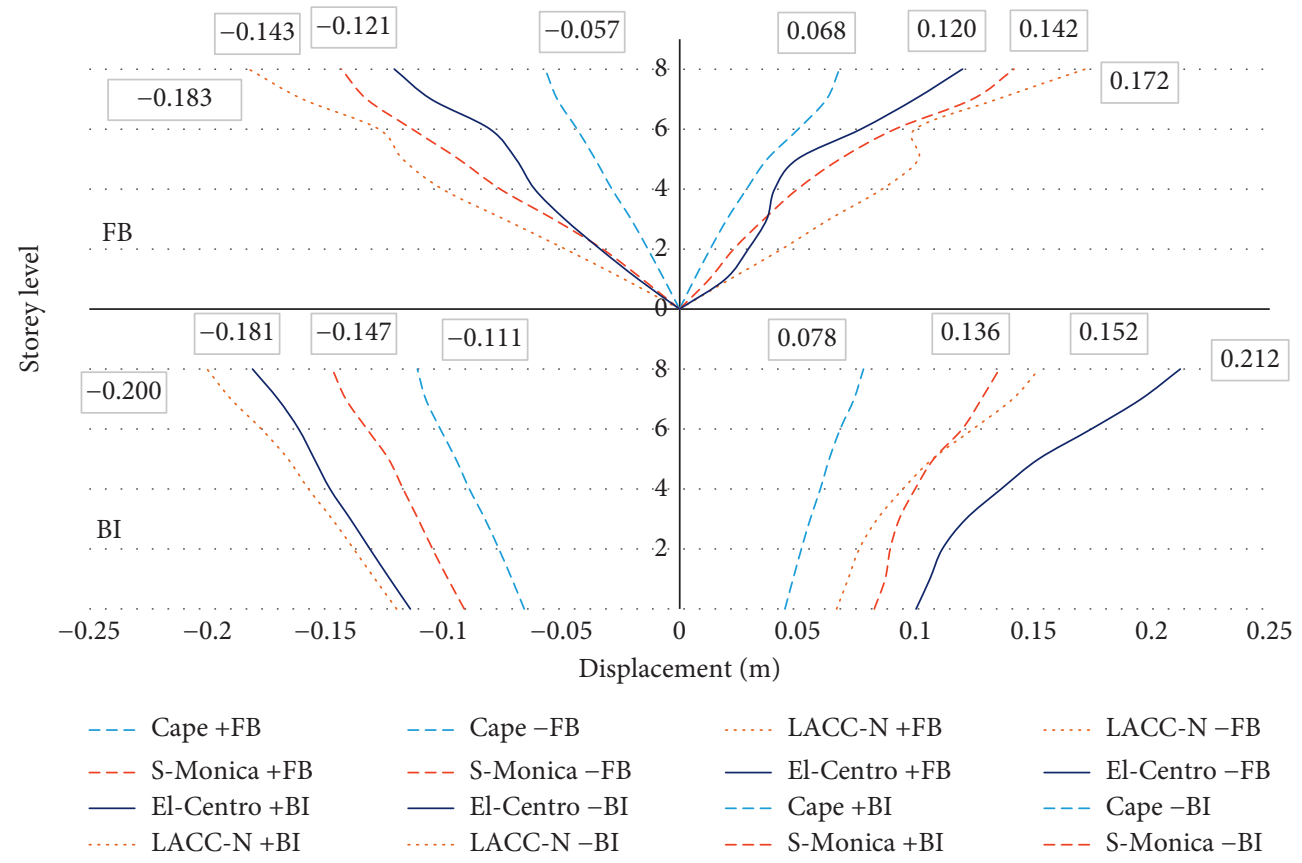

FIGURE 7: Envelope displacements of the taller buildings in different floors under seismic loads.

Herein, an example is given for the building subjected to the El-Centro motion:

Positive relative displacement of the BI building: $13.09-11.3=1.8 \mathrm{~cm}<7.1 \mathrm{~cm}$ for the FB building $(74.6 \%$ reduction). Negative relative displacement of the BI building: $(-9.3)-(-8)=-1.3 \mathrm{~cm}<-5.7 \mathrm{~cm}$ for the FB building (77.2\% reduction).

Overall, taking an average calculation for the relative displacement of the shorter building under different applied motions shows that the BI system is capable to reduce displacement responses up to $77.5 \%$ in the pounding (longitudinal) direction. The values are indicated in Table 4.

Figures 9 and 10 show the displacement time history response of the taller and shorter buildings at the pounding level subjected to the ground motions. In view of the nonlinear displacement responses, it could be concluded that the displacement interval of the FBI buildings has a significant lower oscillation. In other words, the base isolators increased the vibration period of the structures
TABLE 3: Relative displacement of the taller FFB and FBI buildings under considered motions.

\begin{tabular}{|c|c|c|c|c|c|c|}
\hline \multirow[t]{2}{*}{ Earthquake } & \multicolumn{2}{|c|}{$\begin{array}{l}\text { FFB taller } \\
\text { building } \\
\text { disp. }(\mathrm{cm})\end{array}$} & \multicolumn{2}{|c|}{$\begin{array}{l}\text { FBI taller } \\
\text { building } \\
\text { disp. }(\mathrm{cm})\end{array}$} & \multicolumn{2}{|c|}{$\begin{array}{l}\text { Reduction } \\
(\%)\end{array}$} \\
\hline & Pos. & Neg. & Pos. & Neg. & Pos. & Neg. \\
\hline Cape & 6.8 & -5.7 & 3.34 & -4.5 & 51 & 21 \\
\hline LACC-N & 17.2 & -18.3 & 8.6 & -8 & 50 & 56 \\
\hline S-Monica & 14.2 & -14.3 & 5.4 & -5.6 & 62 & 61 \\
\hline El-Centro & 12 & -12.1 & 11.2 & -6.7 & 7 & 45 \\
\hline & & & & Ave. & 42.5 & 46 \\
\hline
\end{tabular}

which led the structures to experience lesser collision during the excitations (Figure 11). In contrary, the adjacent FFB buildings with smaller vibration periods are more prone to high risk of collision. This can increase the damage possibility of the FFB buildings more than FBI buildings during seismic excitations. 


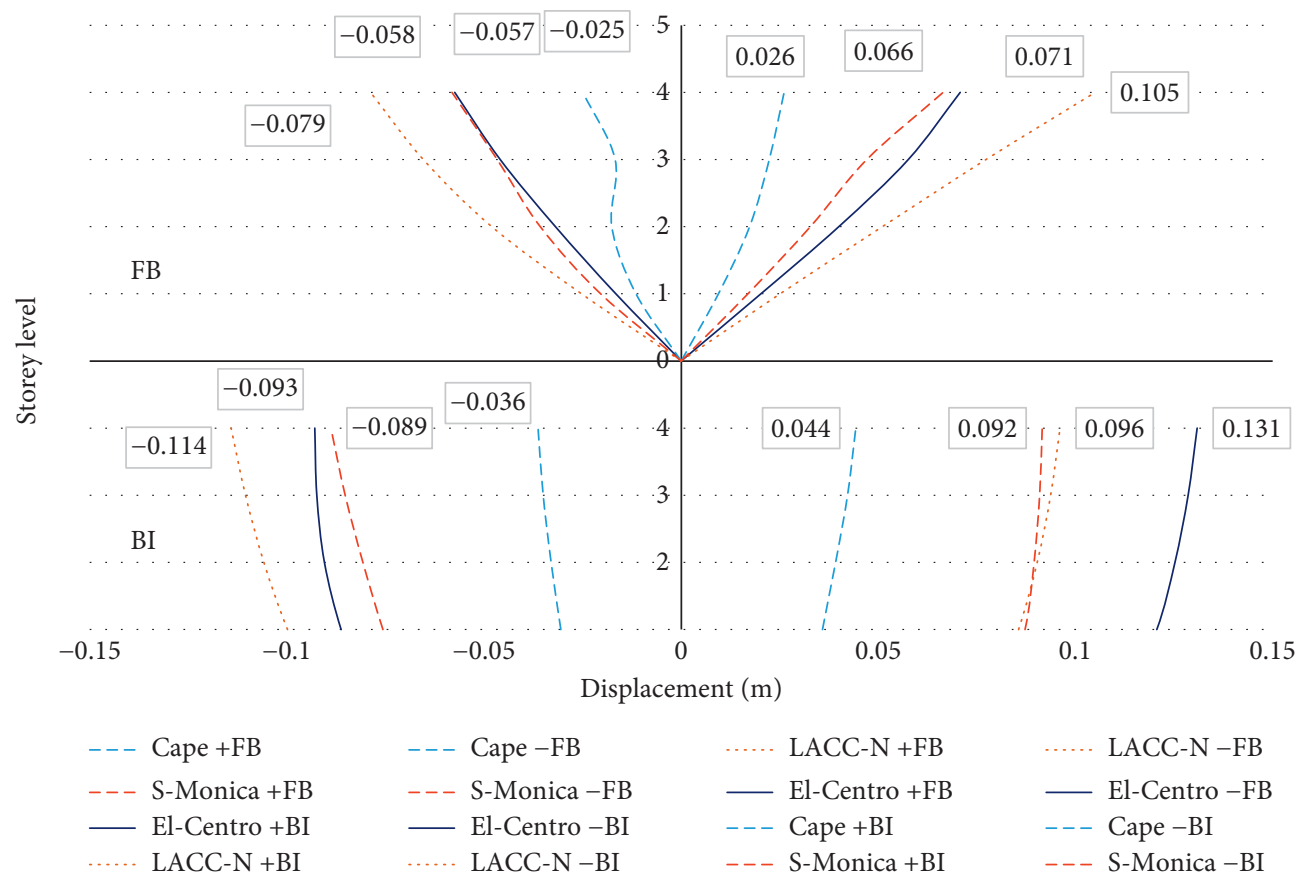

FIGURE 8: Envelope displacements of the shorter buildings in different floors under seismic loads.

TABLE 4: Relative displacement of the shorter FFB and FBI buildings under considered motions.

\begin{tabular}{|c|c|c|c|c|c|c|}
\hline \multirow{2}{*}{ Earthquake } & \multicolumn{2}{|c|}{$\begin{array}{l}\text { FFB shorter building } \\
\text { disp. }(\mathrm{cm})\end{array}$} & \multicolumn{2}{|c|}{$\begin{array}{l}\text { FBI shorter building } \\
\text { disp. }(\mathrm{cm})\end{array}$} & \multicolumn{2}{|c|}{ Reduction (\%) } \\
\hline & Pos. & Neg. & Pos. & Neg. & Pos. & Neg. \\
\hline Cape & 2.6 & -2.5 & 1.1 & -0.8 & 58 & 68 \\
\hline LACC-N & 10.5 & -7.9 & 1.7 & -2.2 & 84 & 72 \\
\hline S-Monica & 6.6 & -5.8 & 1 & -1.9 & 85 & 67 \\
\hline El-Centro & 7.1 & -5.7 & 1.8 & -1.3 & 75 & 77 \\
\hline & & & & Ave. & 75.5 & 71 \\
\hline
\end{tabular}

3.1.3. Acceleration Response. Stopping the displacement in a moment results a rapid and enormous pulse of acceleration at the pounding level in the opposite side. During earthquake excitations, large accelerations will be produced owing to the energetic ground motions. These accelerations may intensify several times once structural pounding happens. Figure 12 illustrates the maximum acceleration response of the buildings for each floor level independently. As it is shown in the figure, the acceleration response of FBI buildings was smaller than those with FB support. However, the first three floors of the FBI adjacent building attracted more accelerations compared to the FFB adjacent buildings under S-Monica excitations. It is because of the structure movement (especially the taller one) at their base level due to the presence of the base isolators. For the taller building, at its first floor, this phenomenon is observed under all earthquakes except LACC-N. As a result of colliding, the adjacent buildings bounce. For this reason, regardless of support systems, the acceleration response of taller buildings is tended in the negative direction and for smaller building is in the positive direction. The maximum accelerations for the taller and shorter FFB adjacent buildings at 4th (pounding), at the contact moment, are depicted in Figure 12. Comparing the values showed that using base isolation system resulted in a significant reduction of acceleration response at the pounding level for both adjacent buildings. Moreover, the absorbed acceleration by the top floor of the taller building also confirmed the effectiveness of the BI system in mitigation of the input acceleration imposed to the buildings. Table 5 indicates the average reduction of acceleration response of the buildings subjected to the motions. From the table, it can be concluded that using BI system mitigates the absorbed acceleration by the adjacent buildings up to $41 \%$ for the taller building and $35 \%$ for the shorter one.

3.1.4. Pounding Force. The greater pounding force increases the collapse risk of buildings during ground motions; therefore, it is much favourable to reduce the pounding force between structures. In addition, pounding is too less important in the transverse direction compared to the perpendicular (principal or longitudinal) direction. An investigation 

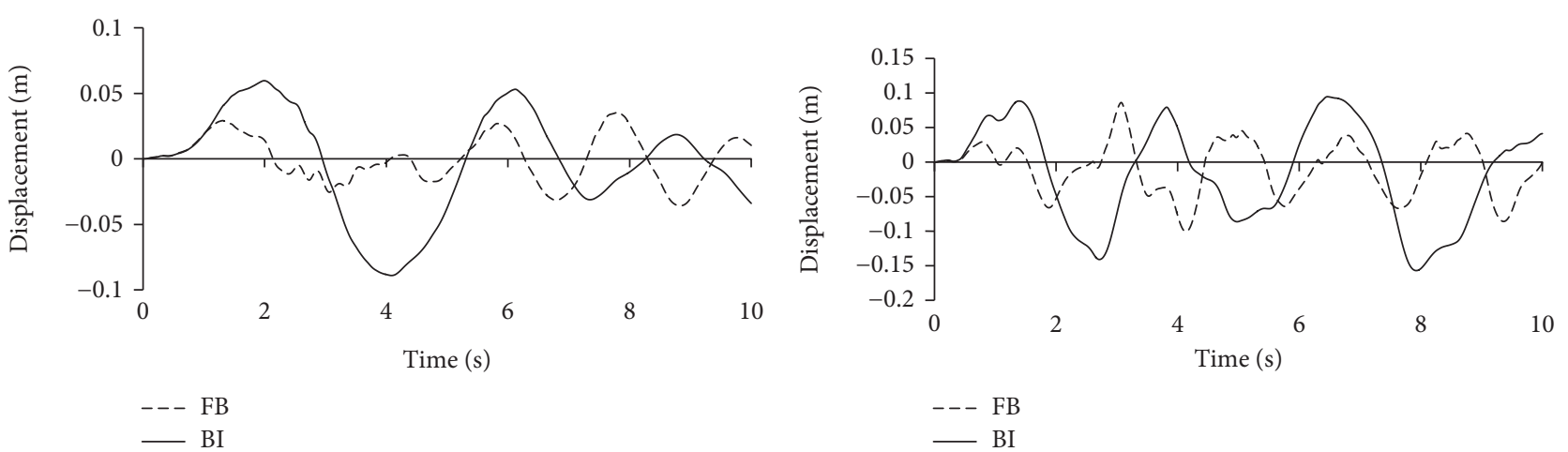

(a)

(b)
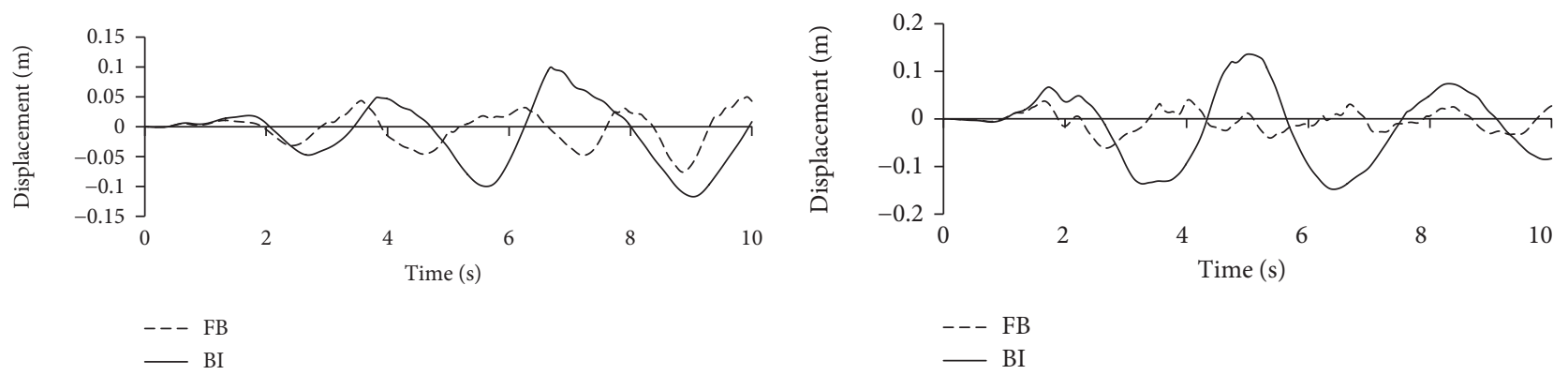

(c)

(d)

Figure 9: Displacement time history response of the taller building at the pounding level under the motions. (a) Cape. (b) LACC-N. (c) S-Monica. (d) El-Centro.
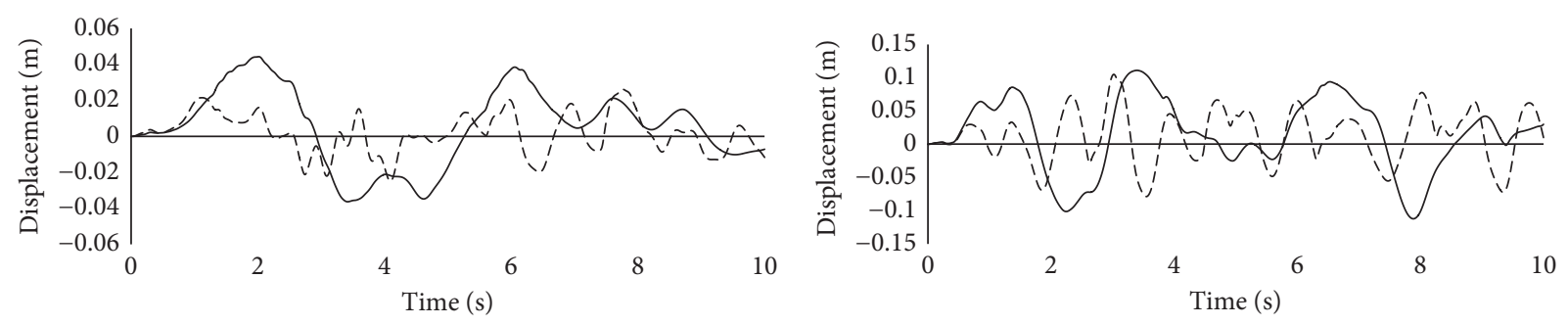

$$
\begin{aligned}
& --- \text { FB } \\
& - \text { BI }
\end{aligned}
$$$$
\begin{aligned}
& --- \text { FB } \\
& - \text { BI }
\end{aligned}
$$

(a)

(b)
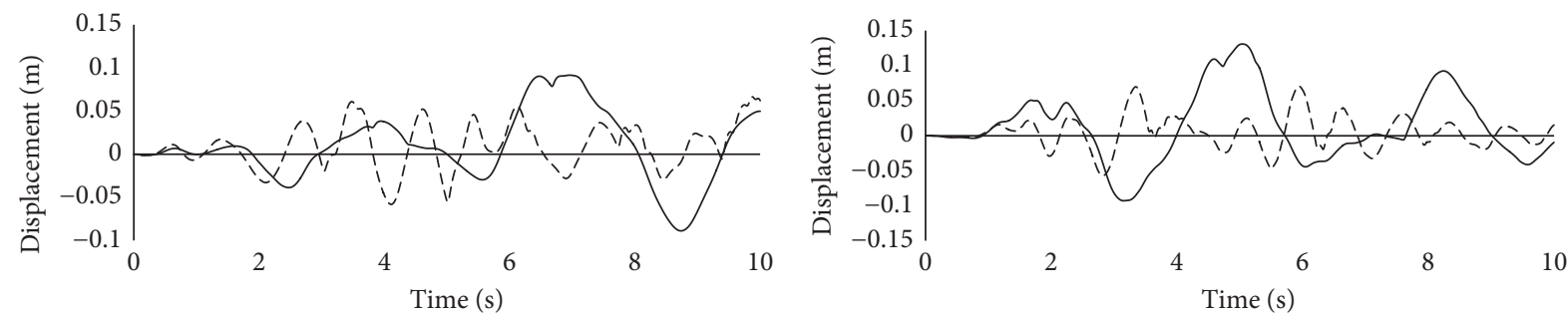

--- FB

--- FB

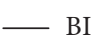

(c)

(d)

FIGURE 10: Displacement time history response of the shorter building at the pounding level under the motions. (a) Cape. (b) LACC-N. (c) S-Monica. (d) El-Centro. 


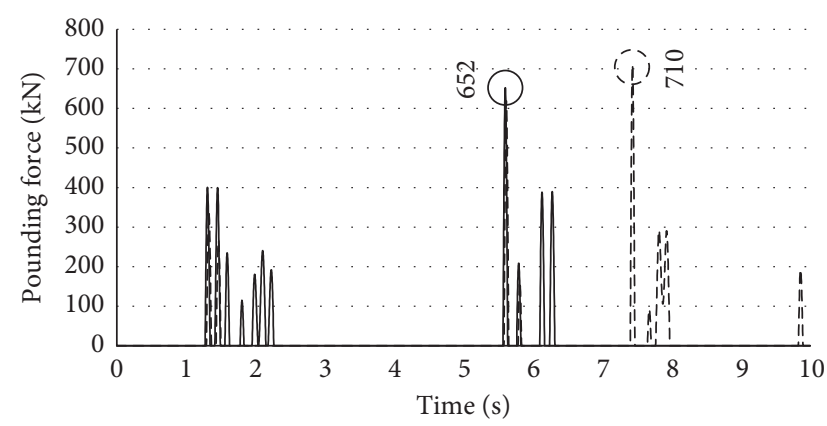

- - Cape FB

(a)

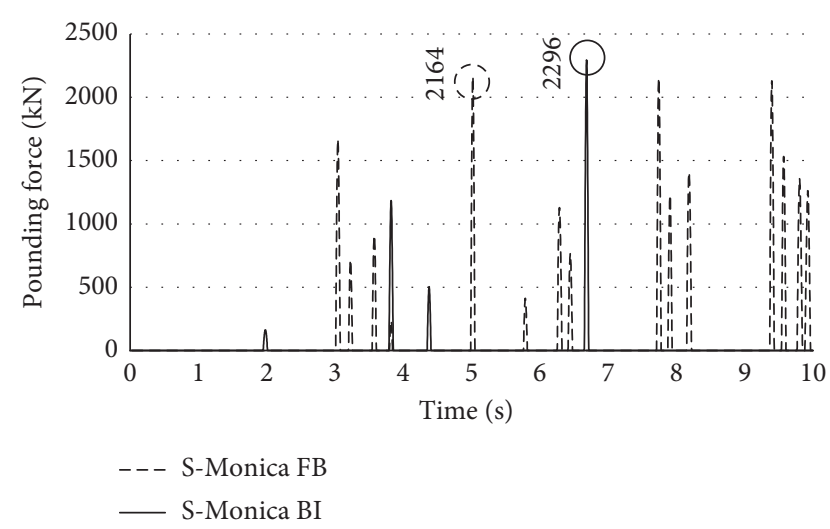

(c)

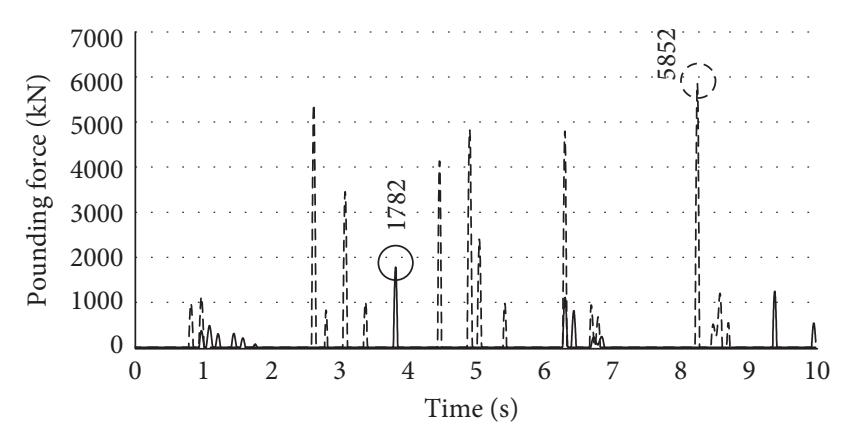

-- - LACC-N FB

- LACC-N BI

(b)

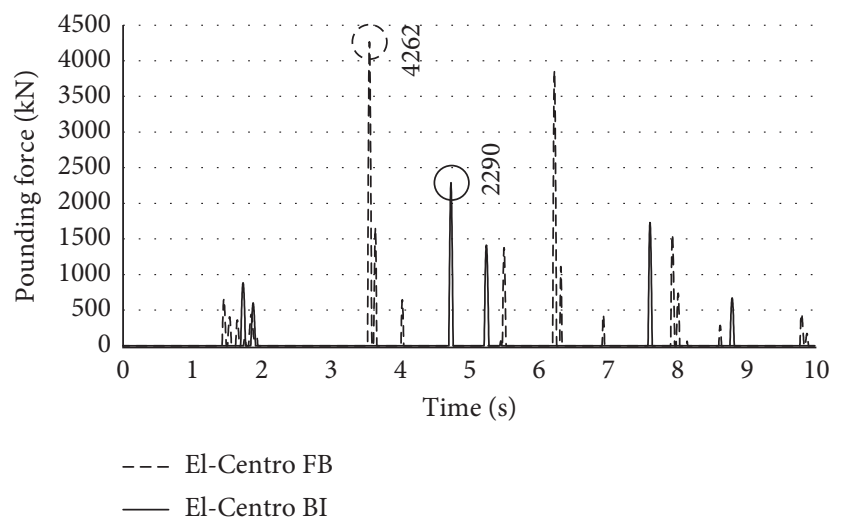

(d)

FIgure 11: Pounding force at the pounding level of FFB and FBI adjacent buildings. (a) Cape. (b) LACC-N. (c) S-Monica. (d) El-Centro.

of structural pounding between stairway tower and main building revealed that the main structure with considerable stiffness and large mass would response for independent vibration and pounding in the transverse direction [35]. This is because, the contact between two adjacent buildings is mostly occurred at the pounding (longitudinal) direction. In the transverse direction, buildings only carry the friction forces. Herein, the time history of pounding force for both FFB and FBI adjacent buildings at the 4th level in the longitudinal direction is presented in Figure 11. Under the different considered earthquakes, the maximum pounding force of FFB buildings was remarkably greater than the pounding force between FBI adjacent buildings. Indeed, uncontrolled movement and oscillation along with short period of vibration in the FFB system lead the buildings to have such pounding. Such great pounding forces result a wide and undesirable movement in adjacent buildings. In addition to this, from the figure, it can be seen that the number of collisions of the FFB adjacent due to the aforementioned reasons is much more compared to the collisions of the FBI buildings.

3.1.5. Time History Base Shear and Base Moment Analysis. One of the significant issues in seismic design of structures is controlling or reducing base shear and base moment response of structures. Figure 13 depicts the base shear time history analysis in the longitudinal $(X)$ and transverse $(Y)$ direction for FFB and FBI adjacent buildings. The maximum shear force in both directions was decreased using LRB devices. It can also be observed from the time history analysis that the absorbed shear in the FBI buildings has very smooth trend, whilst this trend for the FFB adjacent buildings is very harsh. Taking a look at the values presented in Table 6 confirmed that the FBI buildings undertake smaller base shear in the $X$ and $Y$ directions averagely by $52 \%$ and $60 \%$, respectively, as compared to the FFB building. Figure 14 also indicates an example of the reduction of absolute base shear in FBI buildings in comparison to FFB buildings during El-Centro excitations at each one second interval.

The base moment response has direct relationship to the base shear of the structure. Thus, it is predicted that the reduction in values of base moment for the FBI buildings be lesser than that of the FFB buildings in both directions. From Figure 15, it can be concluded that implementation of the LRBs reduced the base moment averagely by $52 \%$ and $61 \%$ (Table 7) in both the longitudinal and transverse directions compared to the base moments in the FFB adjacent buildings. As predicted, the average base moment reduction values are similar to those values obtained for the base shear. It should be noted that because of using LRBs and reduction in the natural frequencies (increased time period) in the BI buildings, the 


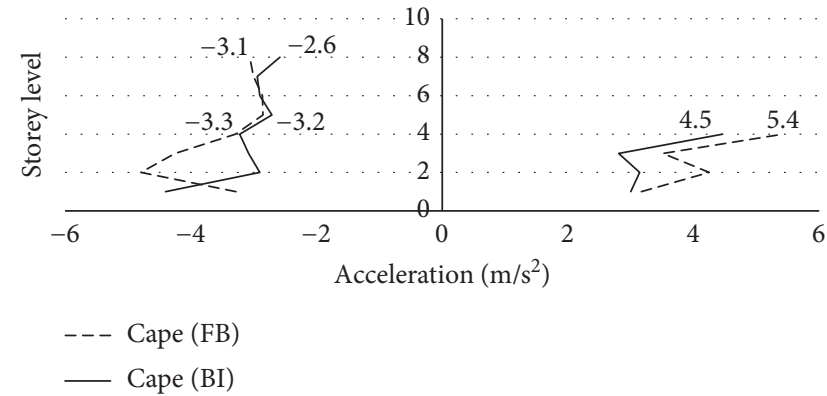

(a)

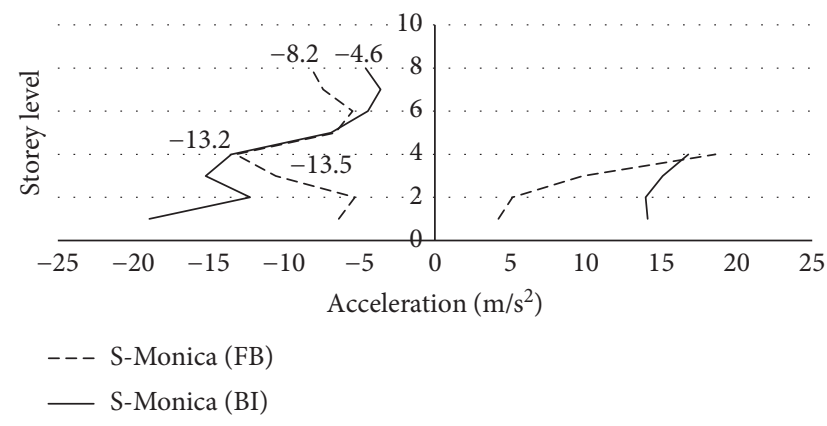

(c)

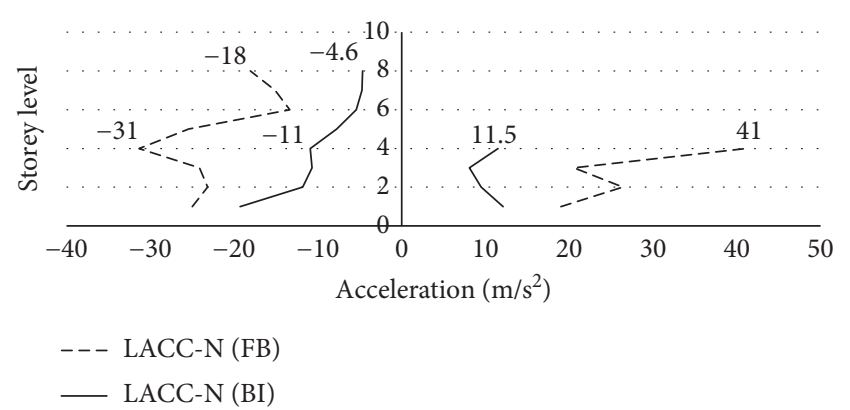

(b)

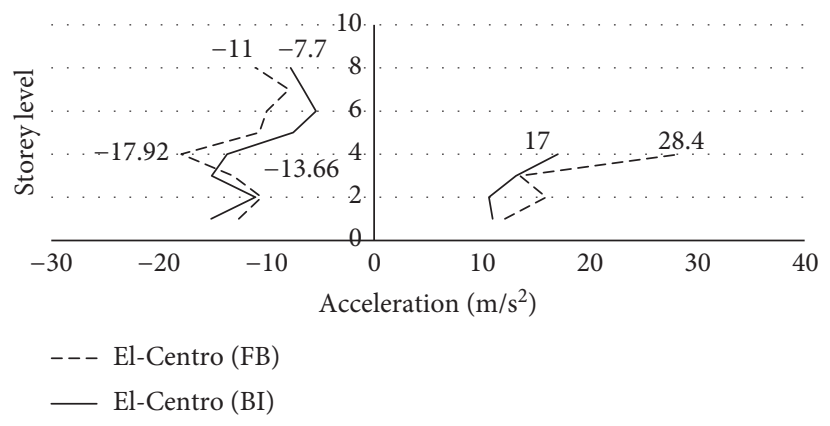

(d)

FIgURE 12: Maximum accelerations of the floor levels of the adjacent buildings under the earthquakes. (a) Cape. (b) LACC-N. (c) S-Monica. (d) El-Centro.

TABLE 5: Acceleration response of the shorter FFB and FBI buildings under considered motions.

\begin{tabular}{|c|c|c|c|c|c|c|}
\hline \multirow{2}{*}{ Earthquake } & \multicolumn{2}{|c|}{ FFB taller building acc. $\left(\mathrm{m} / \mathrm{s}^{2}\right)$} & \multicolumn{2}{|c|}{ FBI taller building acc. $\left(\mathrm{m} / \mathrm{s}^{2}\right)$} & \multicolumn{2}{|c|}{ Reduction (\%) } \\
\hline & 8th floor & 4th floor & 8th floor & 4th floor & 8th & 4 th \\
\hline Cape & -3.1 & -3.3 & -2.6 & -3.2 & 16 & 3 \\
\hline LACC-N & -18 & -31 & -4.6 & -11 & 74 & 65 \\
\hline S-Monica & -8.2 & -13.2 & -4.6 & -13.5 & 44 & 2 \\
\hline El-Centro & -11 & -17.92 & -7.7 & -13.66 & 30 & 24 \\
\hline Ave. & & & & & 41 & 22.5 \\
\hline Earthquake & \multicolumn{2}{|c|}{$\begin{array}{c}\text { FFB shorter building } \\
\text { acc. }\left(\mathrm{m} / \mathrm{s}^{2}\right) \\
\text { 4th floor }\end{array}$} & \multicolumn{2}{|c|}{$\begin{array}{c}\text { FBI shorter building } \\
\text { acc. }\left(\mathrm{m} / \mathrm{s}^{2}\right) \\
\text { 4th floor }\end{array}$} & \multicolumn{2}{|c|}{$\begin{array}{c}\text { Reduction (\%) } \\
\text { 4th }\end{array}$} \\
\hline Cape & \multicolumn{2}{|c|}{5.4} & \multicolumn{2}{|c|}{4.5} & \multicolumn{2}{|c|}{17} \\
\hline LACC-N & \multicolumn{2}{|c|}{41} & \multicolumn{2}{|c|}{11.5} & \multicolumn{2}{|c|}{72} \\
\hline S-Monica & \multicolumn{2}{|c|}{18.6} & \multicolumn{2}{|c|}{16.8} & \multicolumn{2}{|c|}{10} \\
\hline El-Centro & \multirow{2}{*}{\multicolumn{2}{|c|}{28.4}} & \multirow{2}{*}{\multicolumn{2}{|c|}{17}} & \multicolumn{2}{|c|}{40} \\
\hline Ave. & & & & & \multicolumn{2}{|c|}{35} \\
\hline
\end{tabular}

base moment reaction is occurred in a smooth way similar to the base shear, acceleration, and displacement responses as presented earlier. Figure 16 also illustrates an example of the absolute base moment reduction owing to the use of LRBs in each one second interval during El-Centro excitation.

3.1.6. Storey Drift. Structural pounding of buildings demonstrated that the transverse direction has insignificant effect in storey drift [35]. As a result, it can be concluded that the storey drift in the longitudinal (pounding) direction is more perilous. Furthermore, it is commonly accepted that the storey drift of a structure takes changes along its height. In the present study, therefore, the storey drifts of the taller building in the pounding direction considering both systems subjected to the ground motions were investigated as illustrated in Figure 17. Based on the figure, using base isolators not only markedly controls the drift ratio of the building in a better pattern but it also reduces the drift values. In other words, the pattern of the storey drift and the overall structural movement for the taller FBI building 


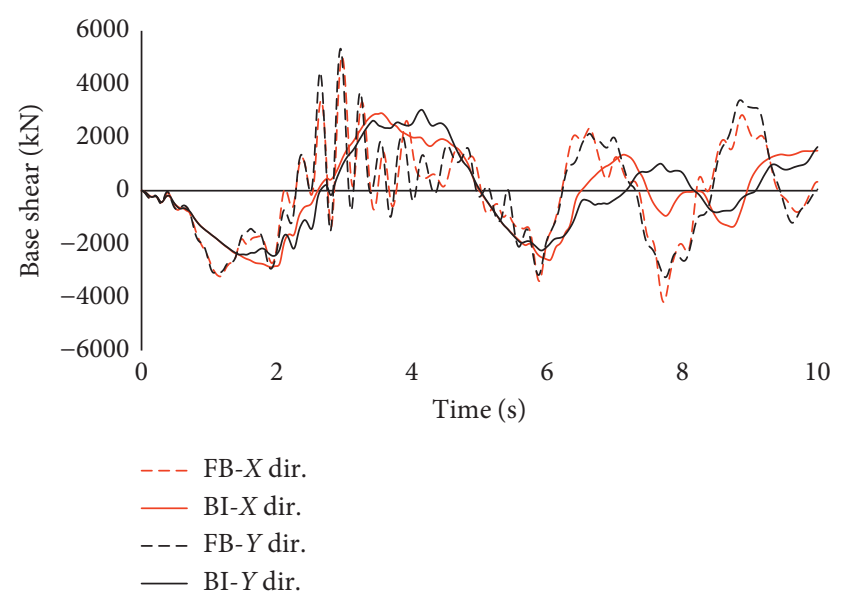

(a)

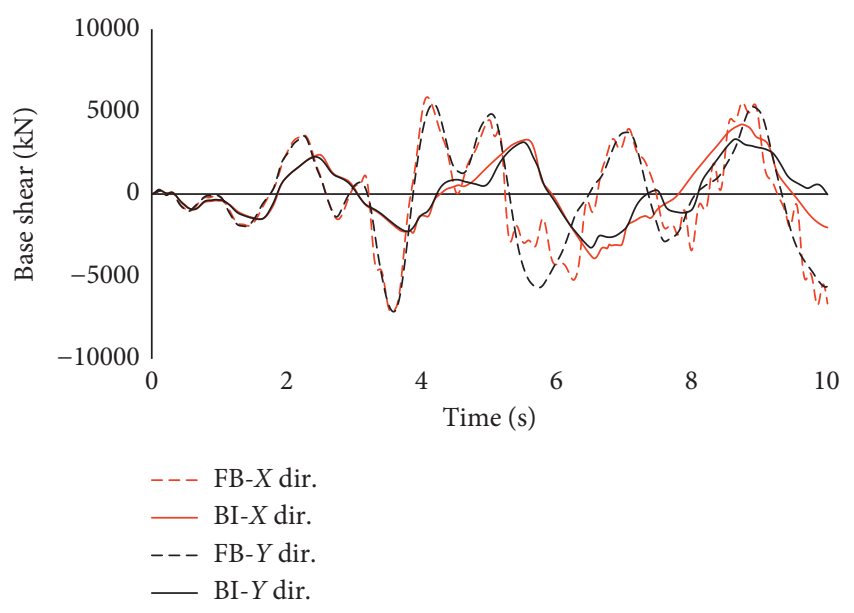

(c)

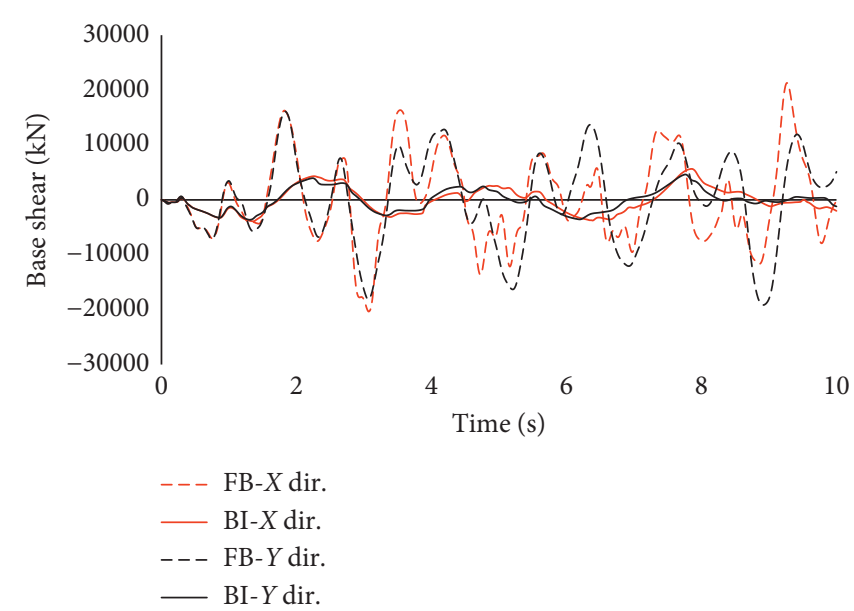

(b)

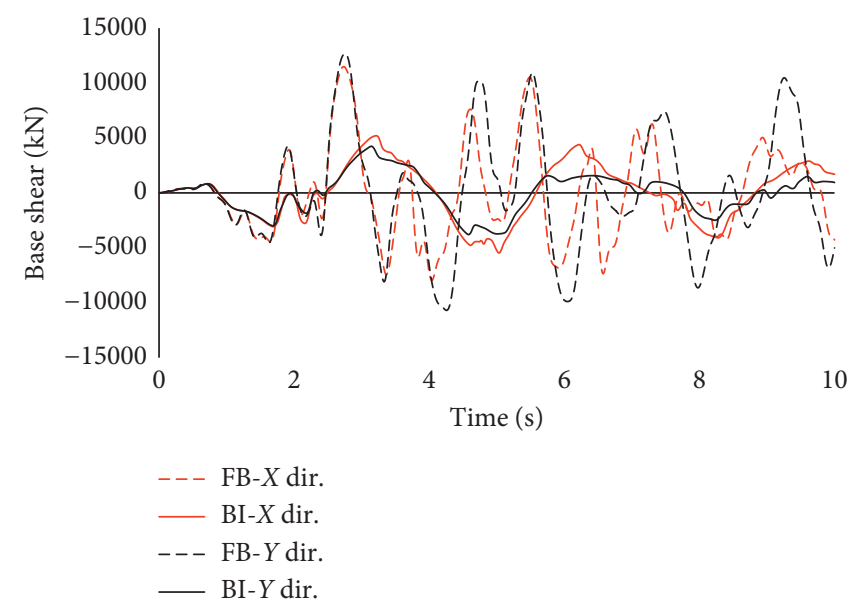

(d)

Figure 13: Base shear for FFB and FBI adjacent buildings under applied earthquakes. (a) Cape. (b) LACC-N. (c) S-Monica. (d) El-Centro.

TABLe 6: Absolute base shear $(\mathrm{kN})$ of the adjacent buildings under applied earthquakes.

\begin{tabular}{|c|c|c|c|c|c|c|}
\hline \multirow{2}{*}{ Earthquake } & \multicolumn{2}{|c|}{ FFB system } & \multicolumn{2}{|c|}{ FBI system } & \multicolumn{2}{|c|}{ Reduction (\%) } \\
\hline & $X$ & $Y$ & $X$ & $Y$ & $X$ & $Y$ \\
\hline Cape & 5043 & 5330 & 2910 & 3036 & 42 & 43 \\
\hline LACC-N & 21,298 & 19,159 & 5646 & 4629 & 73 & 76 \\
\hline S-Monica & 7163 & 7137 & 4223 & 3331 & 41 & 53 \\
\hline El-Centro & 11,495 & 12,679 & 5472 & 4246 & 52 & 67 \\
\hline Ave. & & & & & 52 & 60 \\
\hline
\end{tabular}

shows how the drift of the building was modified. It is because of the existence of LRB devices placed under columns which led the buildings to have a smooth movement during the ground motion.

3.1.7. Storey Shear Force. The variation of shear force for both the FFB and FBI adjacent buildings along the storey levels was compared through Figure 18. Unlike the FFB adjacent buildings, the shear forces in all floors of both taller and shorter FBI buildings were reduced after the implementation of LRBs. As it can be seen from the figure, the shear forces near to the pounding level ( 4 th level) is enlarged due to the collision of both investigated systems of the adjacent buildings. This phenomenon reveals the importance of the design adjacent buildings (particularly structural frames exposed to possible colliding). As a result, the sizes of designed members can remarkably be reduced when base isolation systems are used, leading to more cost-effective and operative system. 


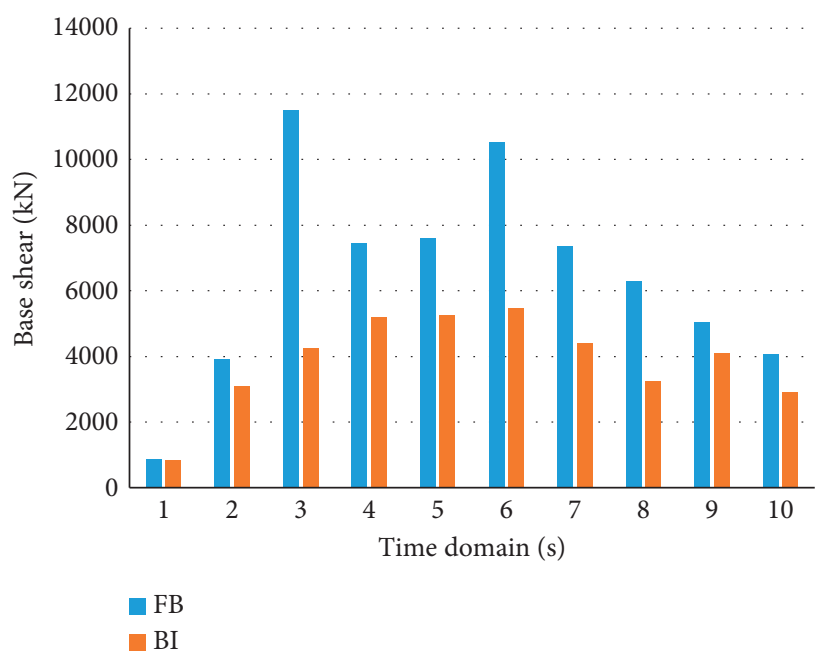

(a)

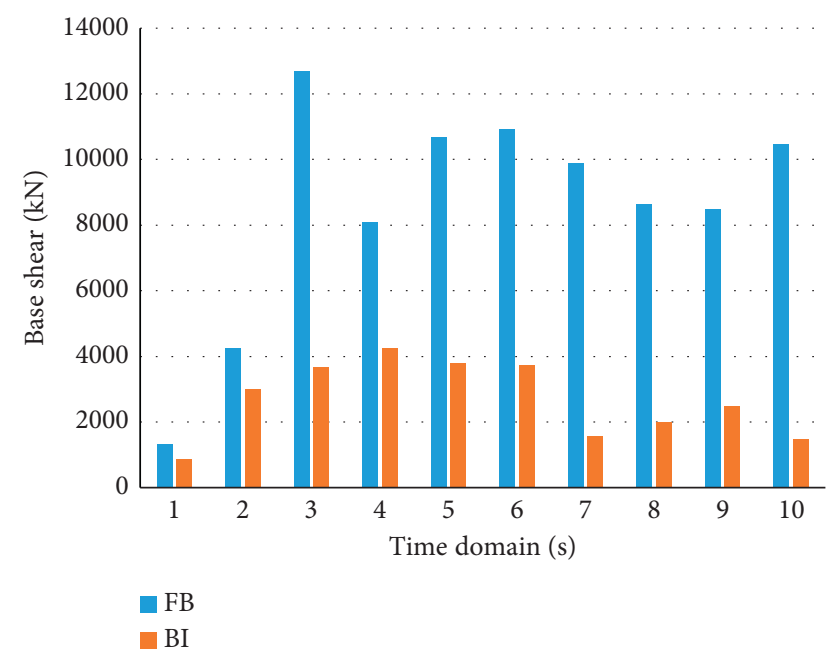

(b)

FIgURE 14: Absolute base shear reduction in FBI adjacent buildings. (a) Longitudinal direction. (b) Transverse direction.

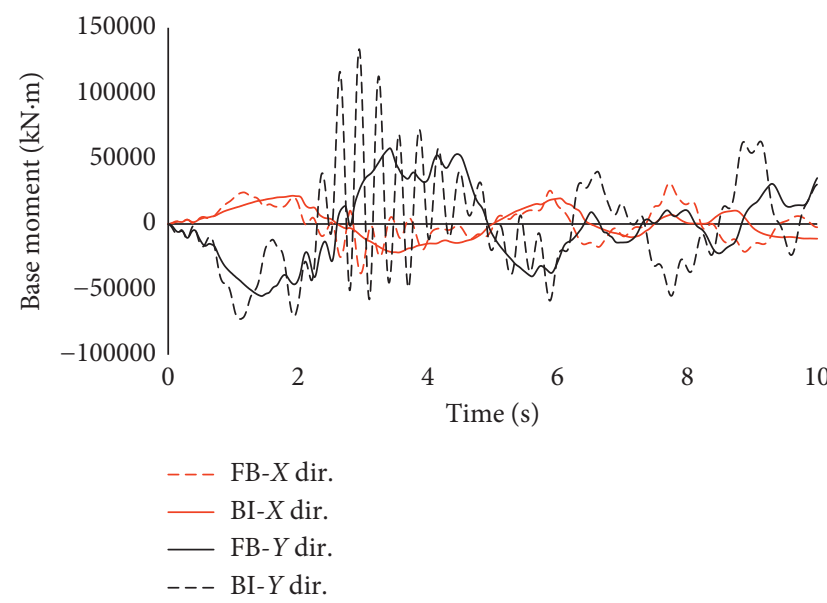

(a)

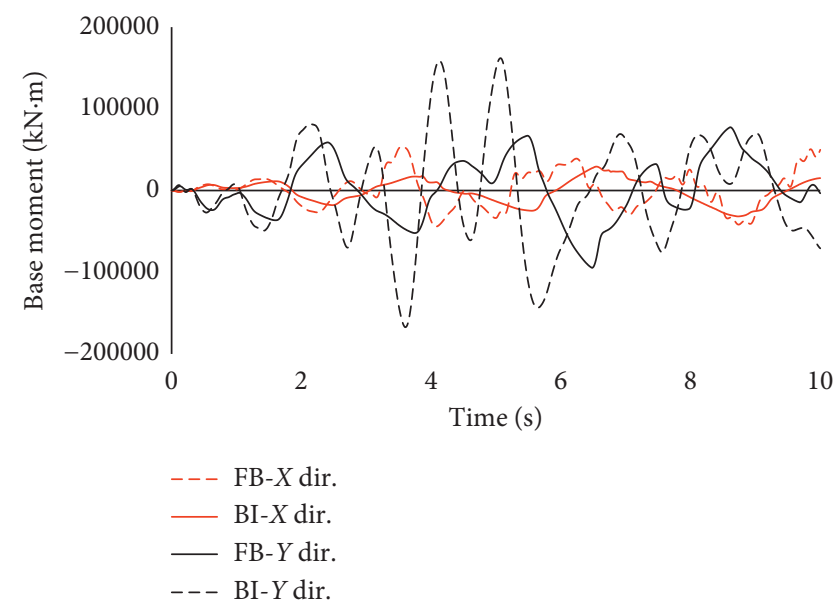

(c)

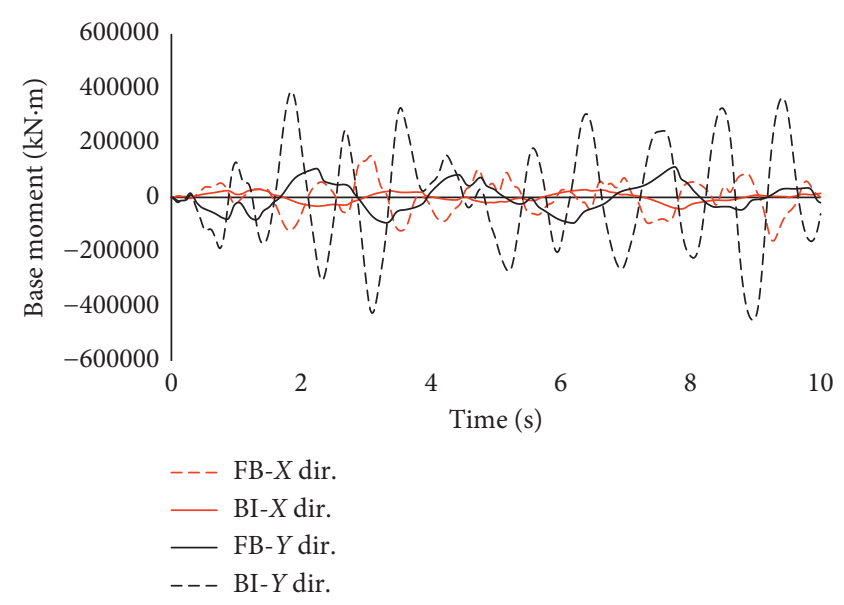

(b)

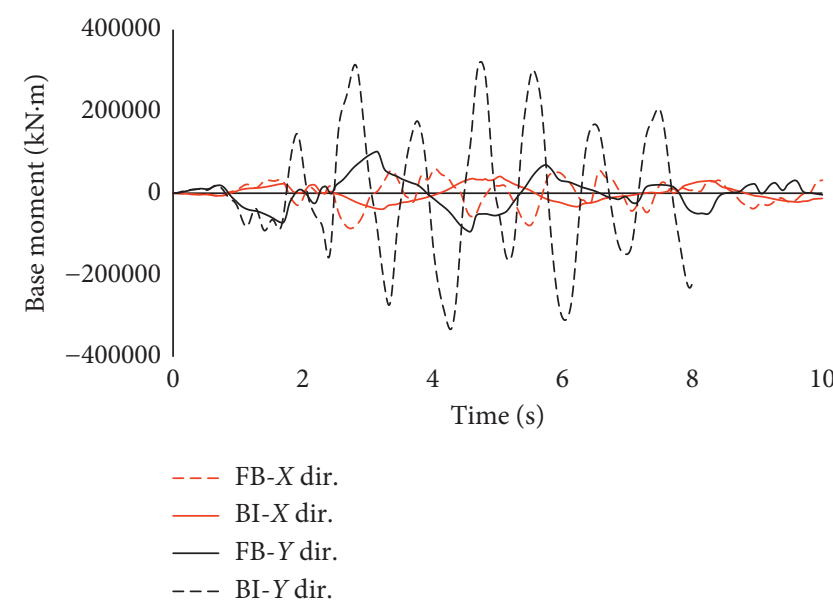

(d)

Figure 15: Base moment for FFB and FBI adjacent buildings under applied earthquakes. (a) Cape. (b) LACC-N. (c) S-Monica. (d) El-Centro. 
TABLE 7: Absolute base moment $(\mathrm{kN} \cdot \mathrm{m})$ of the adjacent buildings under applied earthquakes.

\begin{tabular}{|c|c|c|c|c|c|c|}
\hline \multirow[t]{2}{*}{ Earthquake } & \multicolumn{2}{|c|}{$\begin{array}{l}\text { FFB shorter building disp. } \\
\qquad(\mathrm{cm})\end{array}$} & \multicolumn{2}{|c|}{$\begin{array}{l}\text { FBI shorter building disp. } \\
(\mathrm{cm})\end{array}$} & \multicolumn{2}{|c|}{ Reduction (\%) } \\
\hline & $X$ & $Y$ & $X$ & $Y$ & $X$ & $Y$ \\
\hline Cape & 37,819 & 133,587 & 21,826 & 57,920 & 42 & 57 \\
\hline LACC-N & 159,732 & 450,658 & 42,346 & 112,108 & 73 & 75 \\
\hline S-Monica & 53,719 & 167,263 & 31,674 & 94,593 & 41 & 43 \\
\hline El-Centro & 86,210 & 332,957 & 41,036 & 102,045 & 52 & 69 \\
\hline Ave. & & & & & 52 & 61 \\
\hline
\end{tabular}

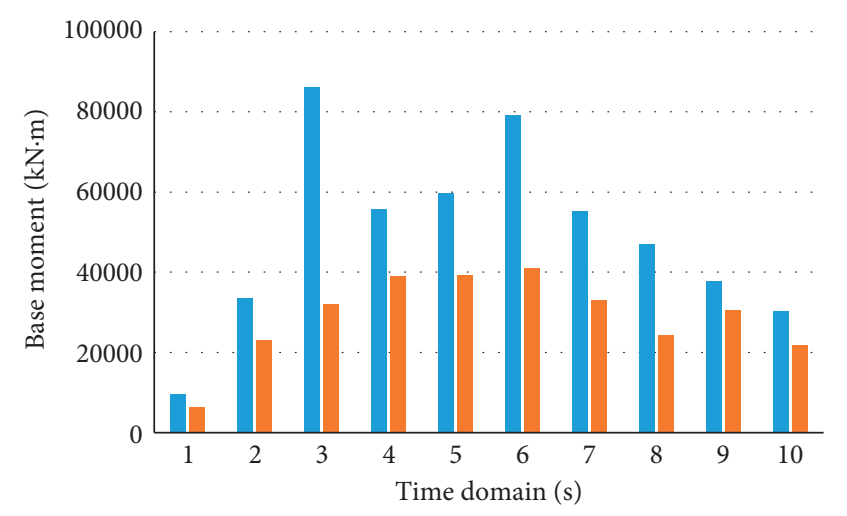

$\mathrm{FB}$

BI

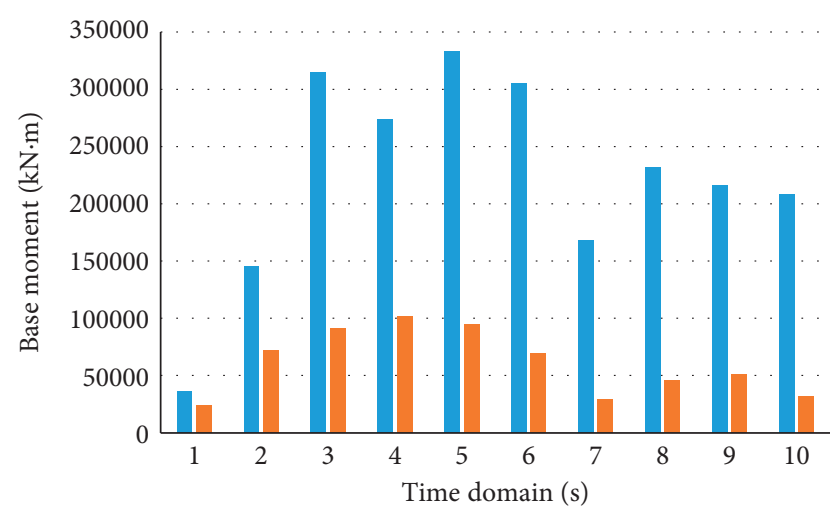

FB $\mathrm{BI}$

(a)

(b)

FIgURE 16: Absolute base moment in FFB and FBI adjacent buildings. (a) Longitudinal direction. (b) Transverse direction.

3.2. Effects of Separation Gap on FBI Adjacent Buildings (Scenario 2). According to previous results, significant reductions were observed for relative displacements, accelerations, pounding forces, base shear, and base moment responses of FBI adjacent buildings. In this section, the FBI adjacent buildings studied above (Figure 5(b)) were chosen to investigate the effects of separation gap on them. To aid the aim, three seismic gaps were modelled as follows:
(1) $30 \mathrm{~mm}$ (Case A)
(2) $170 \mathrm{~mm}$ (Case B)
(3) $300 \mathrm{~mm}$ (Case C)

3.2.1. Displacement Responses. By considering the displacement response of the FBI adjacent building, the taller building had more movement; thus, the authors decided to investigate the displacement responses of the taller building. The displacement response along the floor levels is indicated in Figure 19. As figure shows, the peak displacement for three cases occurred at the roof level of buildings at both positive and negative directions. Toward the positive direction, the maximum displacements were $21.21 \mathrm{~cm}, 21.33 \mathrm{~cm}$, and $21.14 \mathrm{~cm}$ for Case A, B, and C, respectively. Although the displacement values were approximately the same, the motion pattern of the buildings at each floor level for different size of gaps was not similar. The displacement pattern along the floor levels once the seismic gap was $30 \mathrm{~mm}$ and $170 \mathrm{~mm}$ has high-pitched slope in the positive direction, particularly above level 4 (pounding level). This was due to the collision of the shorter building to the taller one at that level. Insofar that the inconsistency of displacement at floors was almost removed in the positive direction for the building with $300 \mathrm{~mm}$ gap size as demonstrated in the figure.

3.2.2. Acceleration Responses. Figure 20 displays the acceleration response of the taller building for different cases along the building height. The building with a $30 \mathrm{~mm}$ separation gap had the peak accelerations along its floors in both positive and negative directions compared to the other two cases. By increasing separation distances between buildings, the acceleration response of each floor reduced. In the positive direction, the maximum accelerations took place with $5.16 \mathrm{~m} / \mathrm{s}^{2}$ at the third floor for $30 \mathrm{~mm}$ gap and $4.912 \mathrm{~m} / \mathrm{s}^{2}$ at the roof level for both $170 \mathrm{~mm}$ and $300 \mathrm{~mm}$ gaps. In contrast, for the negative direction, the peak accelerations with $-15.14 \mathrm{~m} / \mathrm{s}^{2}$ and $-11.27 \mathrm{~m} / \mathrm{s}^{2}$ occurred at the first floor for $30 \mathrm{~mm}$ and $170 \mathrm{~mm}$ gaps, respectively. The above explanations illustrated $4.8 \%$ reduction in acceleration response of the building for Case $\mathrm{B}$ and $\mathrm{C}$ compared to Case $A$, in the positive direction. On the other hand, in the negative direction, there was $30.35 \%$ and $48.2 \%$ acceleration reduction in values which could be seen when the separation gap increased from $30 \mathrm{~mm}$ to $170 \mathrm{~mm}$ and $300 \mathrm{~mm}$, respectively. 


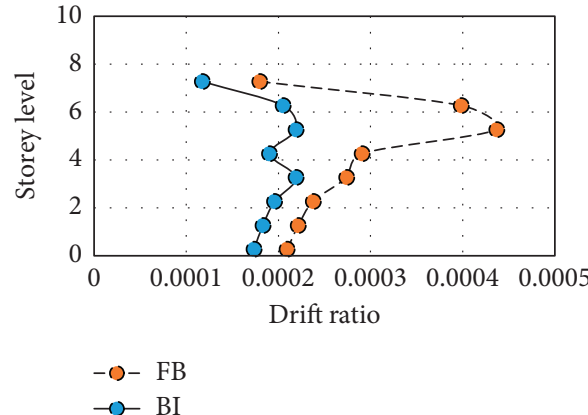

(a)

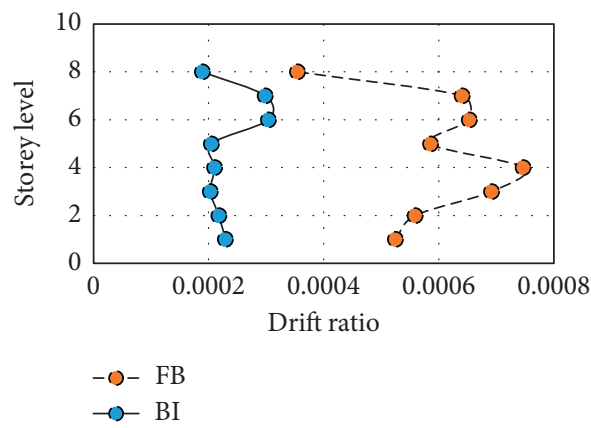

(c)

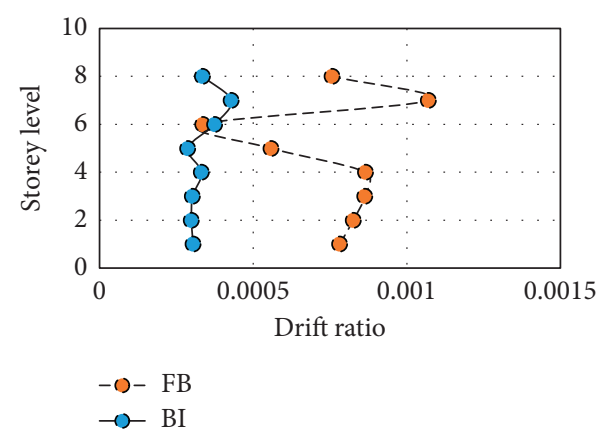

(b)

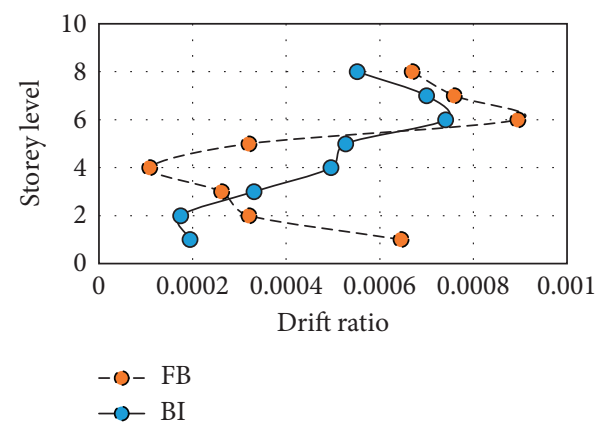

(d)

Figure 17: Storey drift for FFB and FBI buildings. (a) Cape. (b) LACC-N. (c) S-Monica. (d) El-Centro.

3.2.3. Pounding Force. From Table 8, it can be observed that the pounding force was decreased as seismic gaps were increased. The pounding force was $2289.81 \mathrm{kN}, 1920.70 \mathrm{kN}$, and $1366.15 \mathrm{kN}$ for $30 \mathrm{~mm}, 170 \mathrm{~mm}$, and $300 \mathrm{~mm}$ gaps, respectively. It showed a reduction of $16.12 \%$ and $40.3 \%$ for Case B and Case C compared to Case A. Moreover, there was a $28.9 \%$ decrease for Case $\mathrm{C}(300 \mathrm{~mm})$ in comparison to Case B $(170 \mathrm{~mm})$. This consequence demonstrated that a sufficient separation distance between structures would profoundly reduce the pounding damage not only for FBI adjacent buildings but for FFB adjacent buildings as well. Consequently, the damages and collapse of structures reduce when the pounding forces become smaller. In addition to these, Figure 21 depicts the peak pounding forces occurred at 4.74 seconds, 4.93 seconds, and 5.24 seconds for structure with $30 \mathrm{~mm}, 170 \mathrm{~mm}$, and $300 \mathrm{~mm}$ gaps, respectively. This comparison showed that the increase in the separation gap between buildings reduced the collision chance during earthquake excitations. Also, it could be observed that when the gap was only $30 \mathrm{~mm}$, over fifteen times the structures contacted each other, whilst for $170 \mathrm{~mm}$ and $300 \mathrm{~mm}$ seismic gaps, they collided ten and seven times, respectively.

3.2.4. Base Shear and Base Moment. Figure 22 shows the effect of gap distance on the FBI adjacent building in terms of base shear and base moment in both longitudinal and transverse directions. Based on the figure, closer gap resulted higher base shear and base moment in the longitudinal (pounding) direction, although in the transverse direction there was no much difference to carry the shear and moment. This was because in the transverse direction there was no effect of the pounding except a bit frictional force which was reported as a negligible matter [35]. Accordingly, the base shear in the longitudinal direction for Case A was $5471.6 \mathrm{kN}$ and for both cases of B and C was $4351.6 \mathrm{kN}$. In the transverse direction, the base shear for all cases was $4246 \mathrm{kN}$. In addition, the base moment in the longitudinal direction for Case A was $41037 \mathrm{kN} \cdot \mathrm{m}$ and for both cases of B and C was $30567 \mathrm{kN} \cdot \mathrm{m}$. In the transverse direction, the base moment for Case A, B, and C was recorded as $102044 \mathrm{kN} \cdot \mathrm{m}$, $102319 \mathrm{kN} \cdot \mathrm{m}$, and $102573 \mathrm{kN} \cdot \mathrm{m}$, respectively. These small changes in base moment response was due to the existence of that friction force mentioned above.

3.2.5. Storey Drift. The storey drift in Cases A and B had approximately the same tendency; however, it had different trends in Case $\mathrm{C}$ as shown in Figure 23. It was because of the pounding effect in the principal direction. Increase of the seismic gap led the building to experience less pounding force and then having more moderate behaviour. In particular, the maximum drift occurred for the buildings with $30 \mathrm{~mm}$ and $170 \mathrm{~mm}$ gap distance at the 6th floor level with 0.000741 and 0.000535 , respectively. For the building with $300 \mathrm{~mm}$ gap distance, the peak drift happened in the $4 \mathrm{th}$ floor level with 0.000428 . It is concluded that, by increasing the seismic gap between FBI adjacent buildings, the storey drift was reduced and the trend of movement became better. 


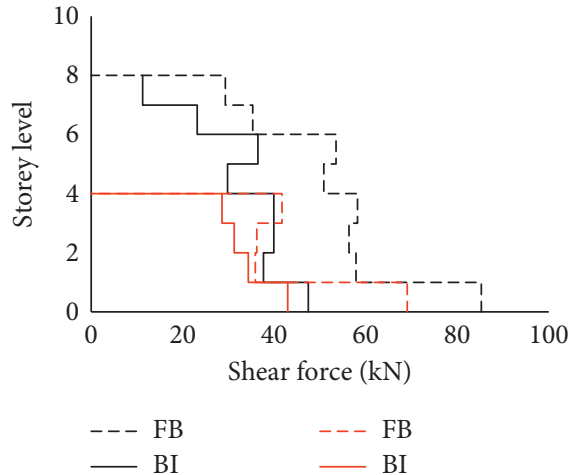

(a)

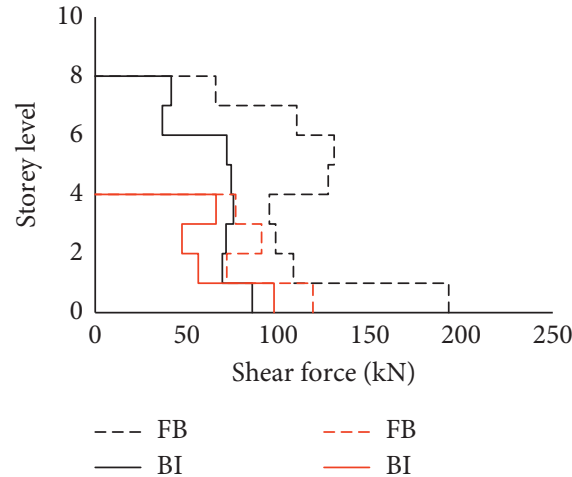

(c)

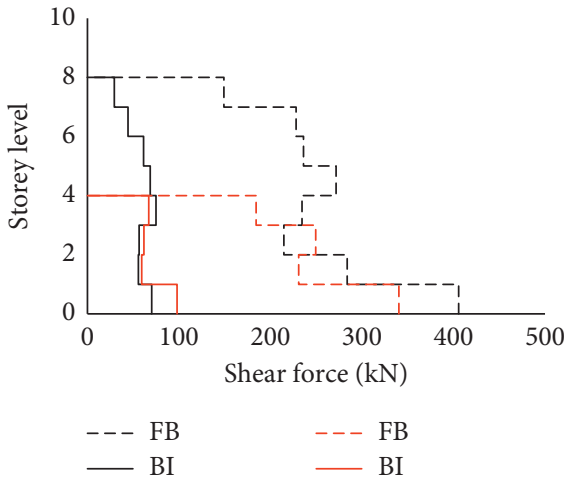

(b)

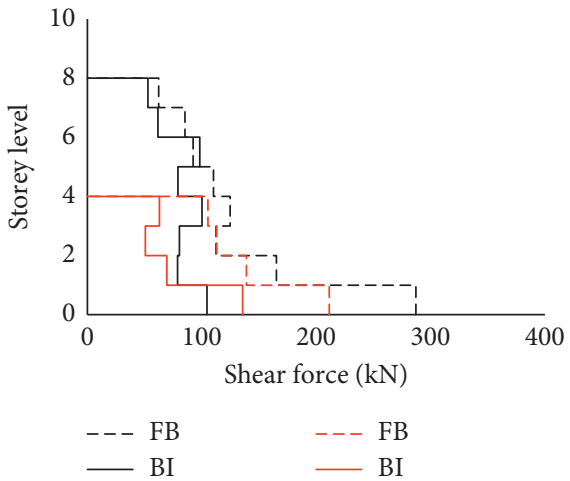

(d)

FIGURE 18: Storey shear force in the adjacent buildings subjected to the different ground motions.

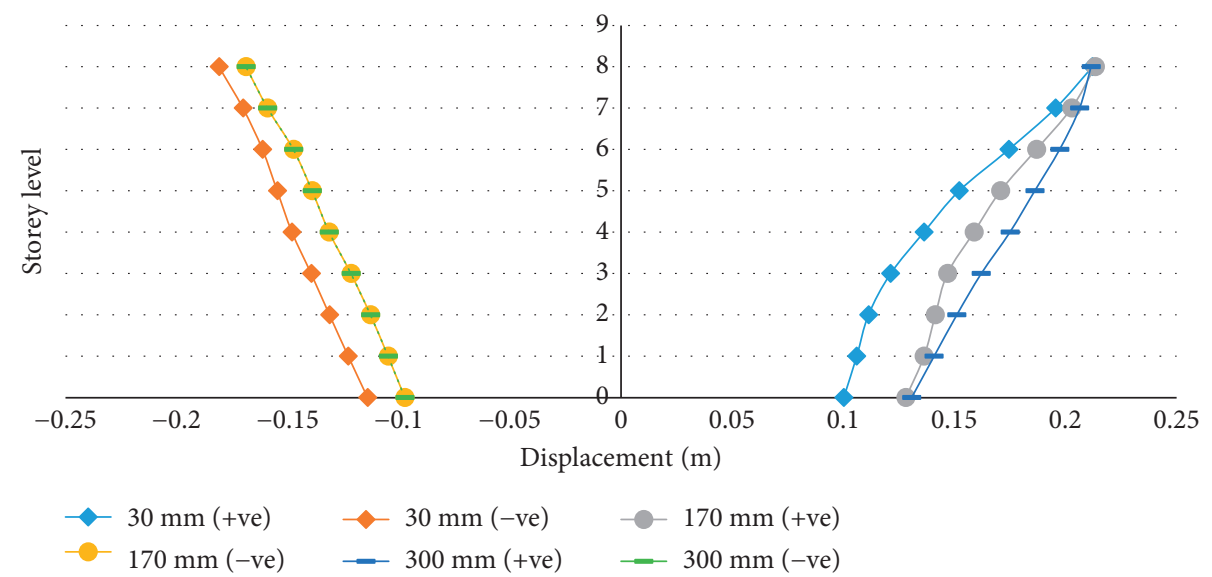

Figure 19: Envelope displacement response of the tall BI buildings considering different seismic gaps.

3.2.6. Hysteresis Behaviour. The hysteresis response of the base isolators used in the current study under longitudinal component of the El-Centro earthquake is shown in Figure 24. As illustrated in the figure, the forces and deformations in the longitudinal direction (principal direction) were changed considering the effect of different gaps between FBI adjacent buildings.

In the shorter building, the force-deformation (F-D) carried by the isolators was $130 \mathrm{kN}-11 \mathrm{~mm}$ in Case A. For both $170 \mathrm{~mm}$ and $300 \mathrm{~mm}$ separation distance, the F-D was similarly $91 \mathrm{kN}-7 \mathrm{~mm}$.

In the taller building, the F-D for Case A was $119 \mathrm{kN}$ $10 \mathrm{~mm}$, and for both Case B and C the F-D was $145 \mathrm{kN}$ $13 \mathrm{~mm}$ and $147 \mathrm{kN}-13 \mathrm{~mm}$, respectively. The behavioural fluctuations of the F-D of isolators were noticeable, spectacularly, for the shorter building, the values of the F-D were decreased as the gap distance between buildings was increased. In contrary, for the taller building, the values of the 


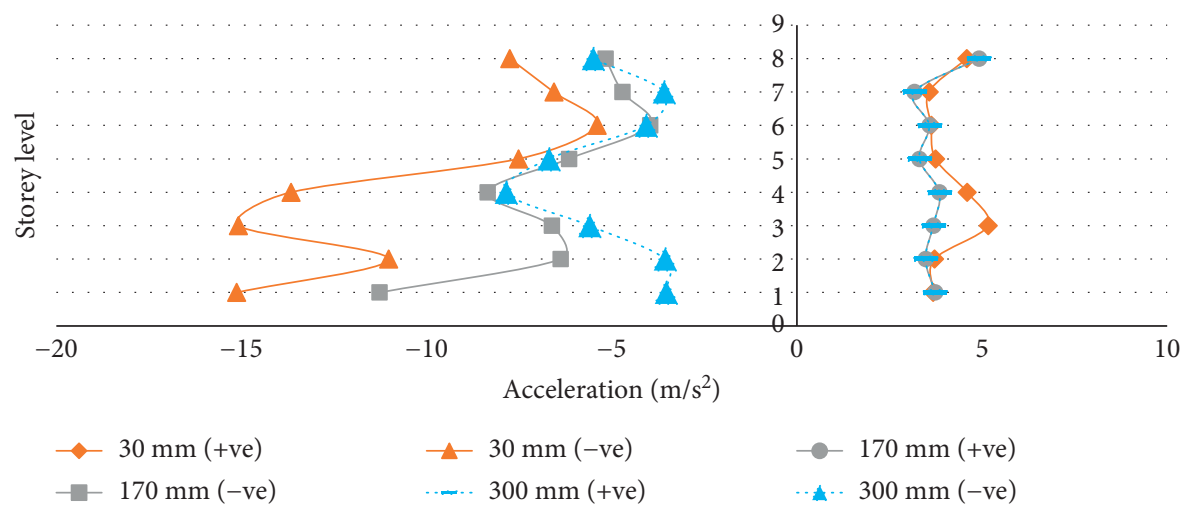

Figure 20: Acceleration response of BI buildings considering different seismic gaps.

TABLE 8: Effect of different seismic gaps on the pounding force at the pounding level.

\begin{tabular}{lccc}
\hline Storey level & Separation distance $(\mathrm{mm})$ & Pounding force $(\mathrm{kN})$ & Time $(\mathrm{s})$ \\
\hline 4 th & 30 & 2289.81 & 4.74 \\
4 th & 170 & 1920.70 & 4.93 \\
th & 300 & 1366.15 & 5.24 \\
\hline
\end{tabular}

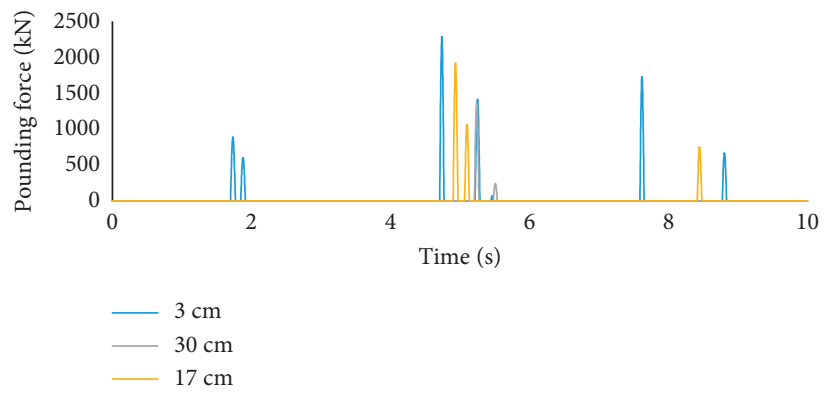

Figure 21: Pounding force considering different seismic gaps.

F-D were increased as the gap distance was increased. Based on these consequences, in design of base isolators for FBI adjacent buildings, it is felt to take the effect of seismic gaps between buildings into consideration.

The overall seismic responses of FBI adjacent buildings considering the effect of different separation gaps are summarized in Table 9. From the table, it can be concluded that to perform a $\mathrm{BI}$ building in vicinity of other $\mathrm{BI}$ buildings, it is a vital need to consider the effect of structural gaps, particularly for those regions with high risk potential of seismic excitations.

\section{Conclusions}

The present study has been divided into two scenarios. In the first scenario, the nonlinear time history responses of the FFB and FBI adjacent buildings under bilateral excitations have been carried out. To study the effect of the base isolation system on seismic response of the FBI adjacent buildings, their performance has been compared to those with FFB support. In the second scenario, three different seismic gaps have been modelled for the FBI adjacent buildings to investigate the effect of separation gaps on response of the FBI adjacent buildings subjected to earthquake load. From both the scenarios and comparative results of the free vibration and time history analyses, the following conclusions can be drawn:

(1) The most impressive option in the study showed that the base isolators resulted in a lower frequency which led the FBI adjacent buildings to have a lower acceleration.

(2) All the displacement, storey drift, acceleration, base shear, and base moment responses of the superstructure of the FBI buildings were much less sensitive, whilst these responses for FFB buildings were increased significantly.

(3) From the relative displacement analysis and acceleration responses of FBI adjacent buildings, it could be concluded that the base isolation system was 


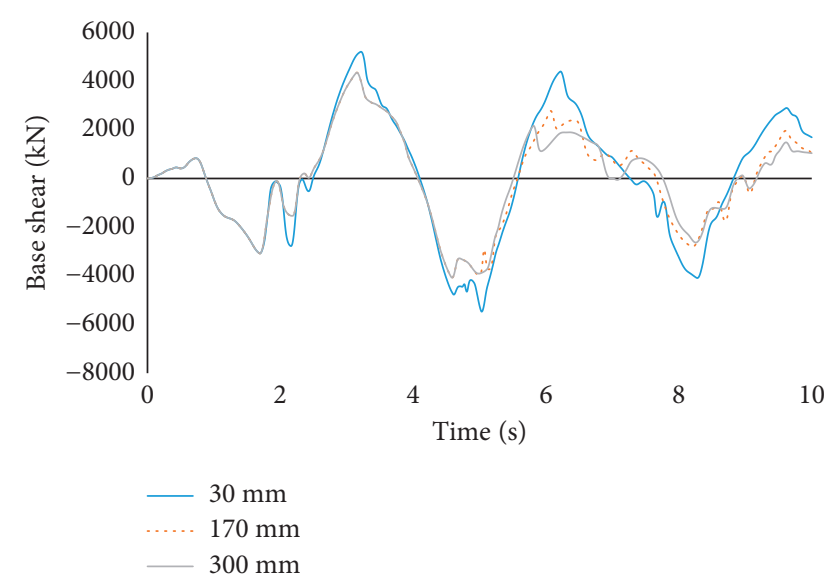

(a)

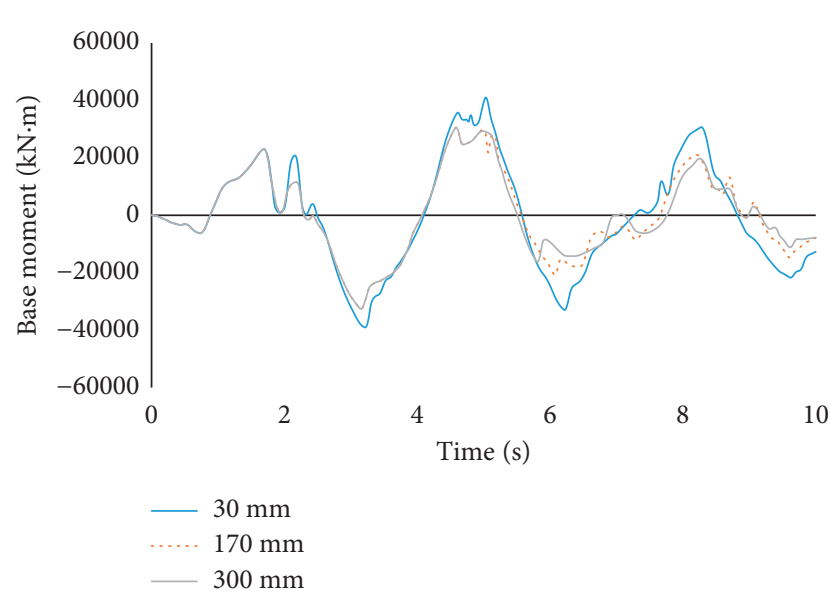

(c)

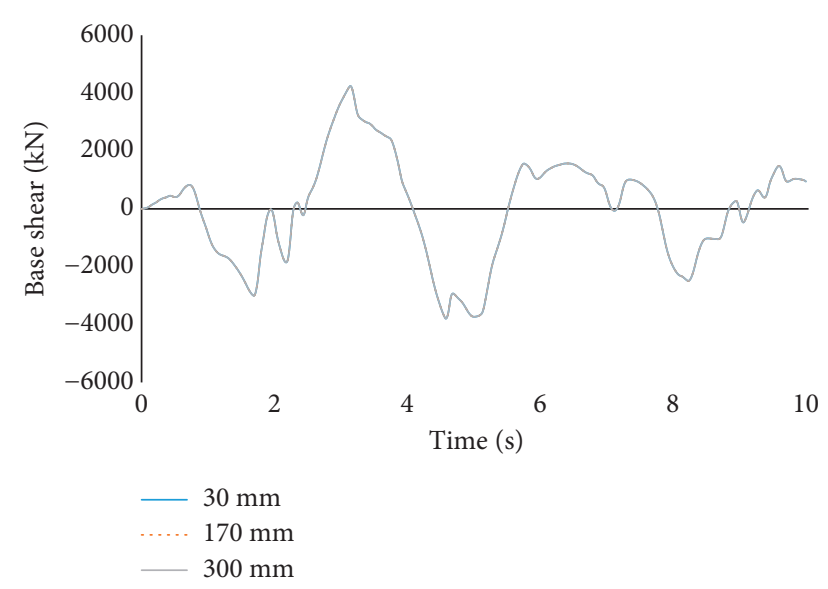

(b)

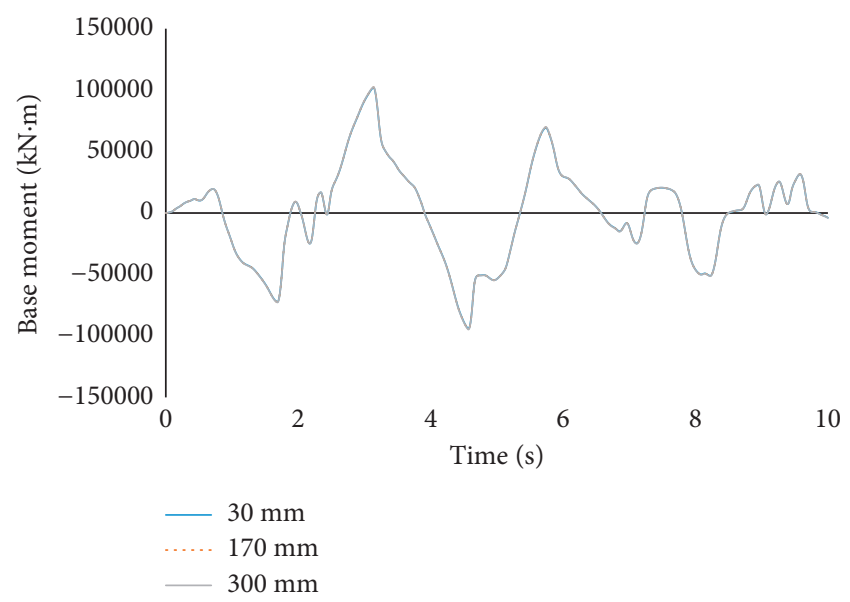

(d)

Figure 22: Effect of seismic gaps on base shear and base moment. (a) Longitudinal direction. (b) Transverse direction. (c) Longitudinal direction. (d) Transverse direction.

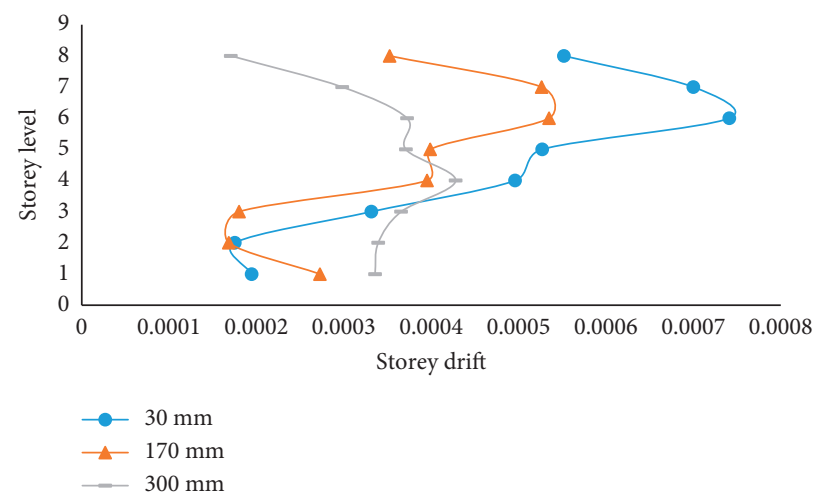

FIGURE 23: Storey drift in each floor level for different separation distances.

further efficient to decrease displacement compared to acceleration.

(4) Shear force in the vertical members and maximum base shear of FBI buildings were reduced significantly.
So, it anticipates fine to save a number of structures as well as supplies economic aid.

(5) Reduction of overturning moment in FBI adjacent buildings makes the buildings more stable in 


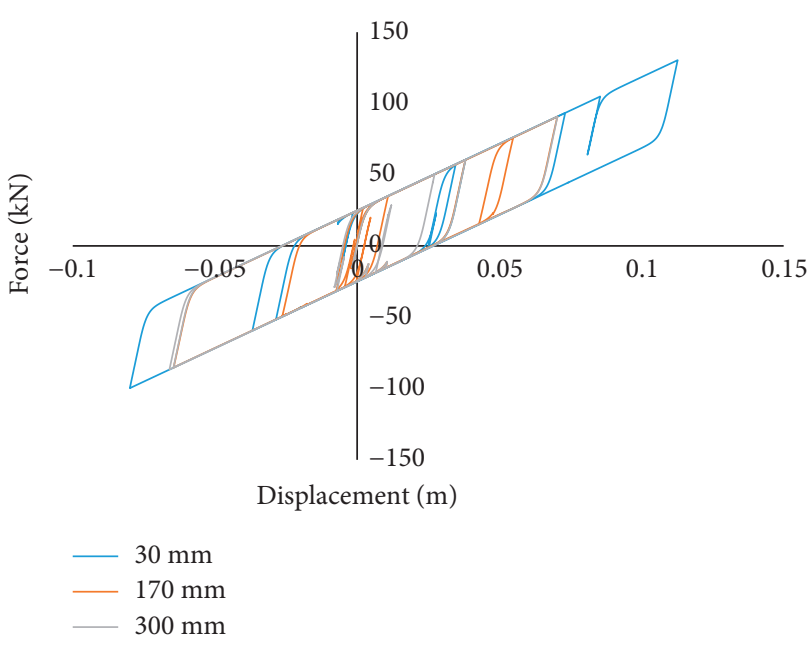

(a)

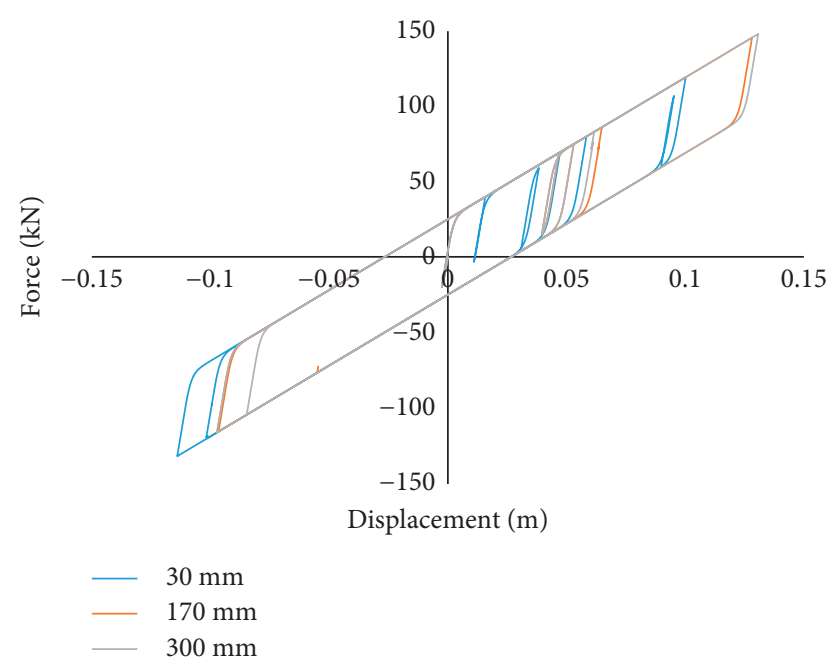

(b)

FIGURE 24: Hysteresis behaviour of LRB devices considering different seismic gaps. (a) Shorter building. (b) Taller building.

TABle 9: Summarized responses of fully BI adjacent buildings considering seismic gaps.

\begin{tabular}{|c|c|c|c|}
\hline \multirow{2}{*}{ Response } & \multicolumn{3}{|c|}{ Gap distance $(\mathrm{mm})$} \\
\hline & 30 & 170 & 300 \\
\hline Pounding force $(\mathrm{kN})$ & 2289.81 & 1920.70 & 1366.15 \\
\hline Dis. ${ }^{\text {(taller building-) }}$ top floor $(\mathrm{cm})$ & 21.21 & 21.33 & 21.14 \\
\hline Dis. ${ }^{\text {(taller building+) }}$ top floor $(\mathrm{cm})$ & -18.09 & -16.88 & -16.88 \\
\hline Acc. ${ }^{\text {taller building- }-)}\left(\mathrm{m} / \mathrm{s}^{2}\right)$ & -15.14 & -11.27 & -7.85 \\
\hline Acc. ${ }^{(\text {taller building+) }}\left(\mathrm{m} / \mathrm{s}^{2}\right)$ & 5.16 & 4.192 & 4.192 \\
\hline $\operatorname{Base} \operatorname{shear}_{(x)}(\mathrm{kN})$ & 5471.6 & 4351.6 & 4351.6 \\
\hline $\operatorname{Base} \operatorname{shear}_{(Y)}(\mathrm{kN})$ & 4246 & 4246 & 4246 \\
\hline 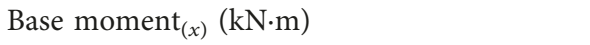 & 41,037 & 30,567 & 30,567 \\
\hline 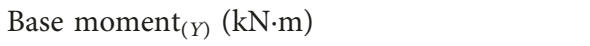 & 102,044 & 102,319 & 102,573 \\
\hline Storey drift ratio & 0.000741 & 0.000535 & 0.000428 \\
\hline F-D of base isolators ${ }^{\text {(taller building) }}(\mathrm{kN} \cdot \mathrm{mm})$ & $119-10$ & $145-13$ & $147-13$ \\
\hline F-D of base isolators ${ }^{\text {(shorter building) }}(\mathrm{kN} \cdot \mathrm{mm})$ & $130-11$ & $91-7$ & $91-7$ \\
\hline
\end{tabular}

-: negative direction; +: positive direction.

comparison to the FFB adjacent buildings. This leads the buildings to experience less contact in both the transverse and longitudinal directions. Allowance of transitionary displacement of support suddenly mutates the trend of entire building deformation.

(6) Closer gap resulted in undesired movements for the middle floors for FBI adjacent buildings. Moreover, closer seismic gap resulted in higher base shear and base moment in the FBI adjacent buildings in the longitudinal (pounding) direction.

(7) As seismic gap increases in FBI adjacent buildings, the number of collisions decreases because of time delay in pounding.

(8) As base isolators affected the displacement pattern of substructure of buildings, the storey drift of the taller BI adjacent building comes into a favourable trend.
(9) The values of the F-D of the base isolators were changed as the seismic gap between buildings was altered. Thus, it is a need to focus on the effect of the seismic gaps on the design of base isolators in future studies.

\section{Conflicts of Interest}

The authors have no conflicts of interest regarding preparation, contribution, and authorship of the present manuscript.

\section{Acknowledgments}

The authors gratefully acknowledge the support given by Fundamental Research Grant Scheme, Ministry of Education, Malaysia (FRGS project no. FP004-2014B), Postgraduate Research Grant (PPP project no. PG177-2016A), 
and University of Malaya Research Grant (UMRG project no. RP004A-13AET).

\section{References}

[1] K. Ghaedi, Z. Ibrahim, H. Adeli, and A. Javanmardi, "Invited review: recent developments in vibration control of building and bridge structures," Journal of Vibroengineering, vol. 19, no. 5, pp. 3564-3580, 2017.

[2] A. Javanmardi, Z. Ibrahim, K. Ghaedi, M. Jameel, H. Khatibi, and M. Suhatril, "Seismic response characteristics of a base isolated cable-stayed bridge under moderate and strong ground motions," Archives of Civil and Mechanical Engineering, vol. 17, no. 2, pp. 419-432, 2017.

[3] M. Gordan, H. A. Razak, Z. Ismail, and K. Ghaedi, "Recent developments in damage identification of structures using data mining," Latin American Journal of Solids and Structures, vol. 14, no. 13, pp. 2373-2401, 2017.

[4] K. Ghaedi and Z. Ibrahim, "Earthquake prediction," in Earthquakes - Tectonics, Hazard and Risk Mitigation, pp. 205-227, InTechOpen, London, UK, 2017.

[5] K. Kasai and B. F. Maison, "Building pounding damage during the 1989 Loma Prieta earthquake," Engineering Structures, vol. 19, no. 3, pp. 195-207, 1997.

[6] E. Rosenblueth and R. Meli, "The 1985 earthquake: causes and effects in Mexico City," Concrete International, vol. 8, pp. 23-24, 1986.

[7] P. Komodromos, P. C. Polycarpou, L. Papaloizou, and M. C. Phocas, "Response of seismically isolated buildings considering poundings," Earthquake Engineering and Structural Dynamics, vol. 36, no. 12, pp. 1605-1622, 2007.

[8] S. Mahmoud and R. Jankowski, "Pounding-involved response of isolated and non-isolated buildings under earthquake excitation," Earthquakes and Structures, vol. 1, no. 3, pp. 231252, 2010.

[9] P. C. Polycarpou and P. Komodromos, "Earthquake-induced poundings of a seismically isolated building with adjacent structures," Earthquake Engineering and Structural Dynamics, vol. 39, no. 8, pp. 933-940, 2010.

[10] M. Jameel, A. B. M. S. Islama, R. R. Hussain, S. D. Hasan, and M. Khaleel, "Non-linear FEM analysis of seismic induced pounding between neighbouring multi-storey structures," Latin American Journal of Solids and Structures, vol. 10, no. 5, pp. 921-939, 2013.

[11] R. Jankowski, "Earthquake-induced pounding between equal height buildings with substantially different dynamic properties," Engineering Structures, vol. 30, no. 10, pp. 2818-2829, 2008.

[12] S. E. Abdel Raheem, "Mitigation measures for earthquake induced pounding effects on seismic performance of adjacent buildings," Bulletin of Earthquake Engineering, vol. 12, no. 4, pp. 1705-1724, 2014.

[13] A. V. Bhaskararao and R. S. Jangid, "Seismic response of adjacent buildings connected with friction dampers," Bulletin of Earthquake Engineering, vol. 4, pp. 43-64, 2006.

[14] V. Jeng and W. Tzeng, "Assessment of seismic pounding hazard for Taipei City," Engineering Structures, vol. 22, no. 5, pp. 459-471, 2000.

[15] J. H. Lin and C. C. Weng, "Spectral analysis on pounding probability of adjacent buildings," Engineering Structures, vol. 23 , no. 7, pp. 768-778, 2001.

[16] B. Madani, F. Behnamfar, and H. Tajmir Riahi, "Dynamic response of structures subjected to pounding and structure-soil-structure interaction," Soil Dynamics and Earthquake Engineering, vol. 78, pp. 46-60, 2015.

[17] K.-S. Park and S.-Y. Ok, "Hybrid control approach for seismic coupling of two similar adjacent structures," Journal of Sound and Vibration, vol. 349, pp. 1-17, 2015.

[18] Y. L. Xu, S. Zhan, J. M. Ko, and W. S. Zhang, "Experimental investigation of adjacent buildings connected by fluid damper," Earthquake Engineering and Structural Dynamics, vol. 28, pp. 609-631, 1999.

[19] A. B. M. Islam, M. Jameel, S. I. Ahmad, and M. Z. Jumaat, "Study on corollary of seismic base isolation system on buildings with soft storey," International Journal of Physical Science, vol. 6, no. 11, pp. 2654-2661, 2011.

[20] A. B. M. Islam, M. Jameel, and M. Z. Jumaat, "Seismic isolation in buildings to be a practical reality: behavior of structure and installation technique," Journal of Engineering and Technology Research, vol. 3, no. 4, pp. 97-117, 2011.

[21] A. B. M. S. Islam, R. Rizwan, M. Jameel, and M. Zamin, "Nonlinear time domain analysis of base isolated multi-storey building under site specific bi-directional seismic loading," Automation in Construction, vol. 22, no. 22, pp. 554-566, 2012.

[22] Z. Ren, C. J. Anumba, G. Augenbroe, and T. M. Hassan, “A functional architecture for an e-Engineering hub," Automation in Construction, vol. 17, no. 8, pp. 930-939, 2008.

[23] J. Penzien, "Evaluation of building separation distance required to prevent pounding during strong earthquakes," Earthquake Engineering and Structure Dynamics, vol. 26, no. 8, pp. 849-858, 1997.

[24] K. Kasai, A. Jagiasi, and V. Jeng, "Inelastic vibration phase theory for seismic pounding mitigation," Structural Engineering, vol. 122, no. 10, pp. 1136-1146, 1996.

[25] H. Hao and S. R. Zhang, "Spatial ground motion effect on relative displacement of adjacent building structures," Earthquake Engineering and Structural Dynamics, vol. 28, no. 4, pp. 333-349, 1999.

[26] B. Shrestha, "Effects of separation distance and nonlinearity on pounding response of adjacent structures," International Journal of Civil Engineering and Structural Engineering, vol. 3, no. 3, pp. 603-612, 2013.

[27] V. K. Agarwal, J. M. Niedzwecki, and J. W. van de Lindt, "Earthquake induced pounding in friction varying base isolated buildings," Engineering Structures, vol. 29, no. 11, pp. 2825-2832, 2007.

[28] S. Khatiwada, N. Chouw, and J. W. Butterworth, "A generic structural pounding model using numerically exact displacement proportional damping," Engineering Structures, vol. 62-63, pp. 33-41, 2014.

[29] Building Seismic Safety Council for the Federal Emergency Management Agency, "NEHRP recommended provisions for seismic regulations for new buildings and other structures," Rep. No. Fema 368, Building Seismic Safety Council, Washington, DC, USA, 2001.

[30] E. L. Wilson, Three-Dimensional Static and Dynamic Analysis of Structures, Computers and Structures, Inc., Berkeley, CA, USA, 2002.

[31] T. E. Kelly, Base Isolation of Structures: Design Guidelines, Holmes Consulting Group Ltd, Auckland, New Zealand, 2001.

[32] T. E. Kelly, W. H. Robinson, and R. I. Skinner, Seismic Isolation for Designers and Structural Engineers, Robinson seismic Ltd., Wellington, New Zealand, 2006.

[33] F. Naeim and J. Kelly, Design of Seismic Isolated Structures: From Theory to Practice, Wiley, Hoboken, NJ, USA, 1999. 
[34] Building and Housing Research Center, Iranian Code of Practice for Seismic Resistant Design of Buildings (Standard No. 2800), Building and Housing Research Center, Tehran, Iran, 3rd edition, 2007.

[35] R. Jankowski, "Non-linear FEM analysis of earthquakeinduced pounding between the main building and the stairway tower of the Olive View Hospital," Engineering Structures, vol. 31, no. 8, pp. 1851-1864, 2009.

[36] R. Jankowski, "Non-linear viscoelastic modelling of earthquake-induced structural pounding," Earthquake Engineering and Structural Dynamics, vol. 34, no. 6, pp. 595-611, 2005.

[37] M. U. Hanif, Z. Ibrahim, M. Jameel, K. Ghaedi, and M. Aslam, "A new approach to estimate damage in concrete beams using non-linearity," Construction and Building Materials, vol. 124, no. 11, pp. 1081-1089, 2016.

[38] K. Ghaedi, F. Hejazi, Z. Ibrahim, and P. Khanezaei, "Flexible foundation effect on seismic analysis of Roller Compacted Concrete (RCC) dams using finite element method," KSCE Journal of Civil Engineering, pp. 1-13, 2017. 


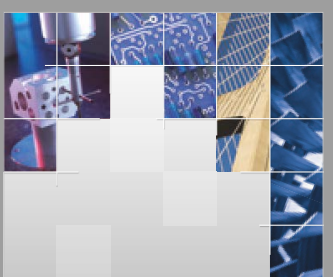

\section{Enfincering}
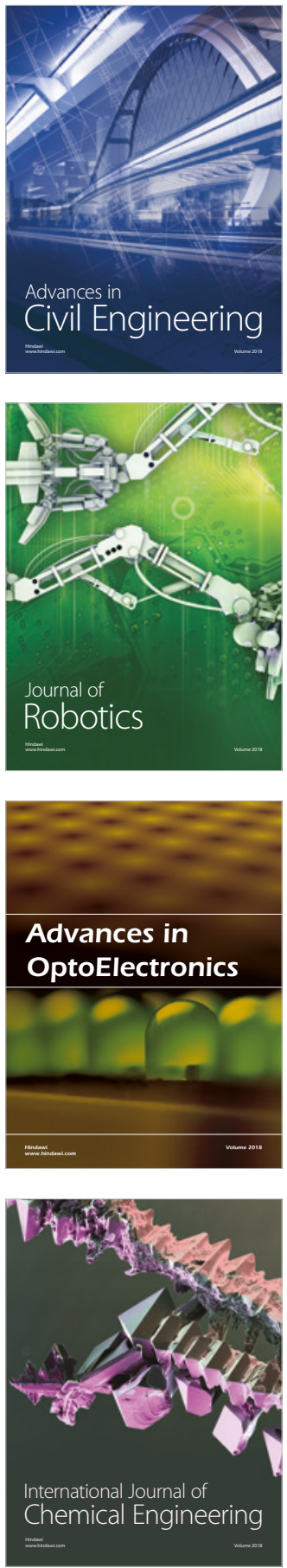

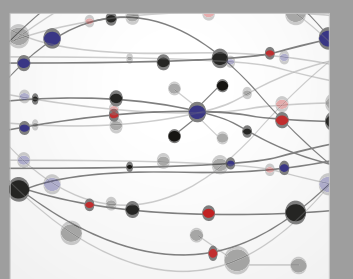

\section{Rotating \\ Machinery}

The Scientific World Journal

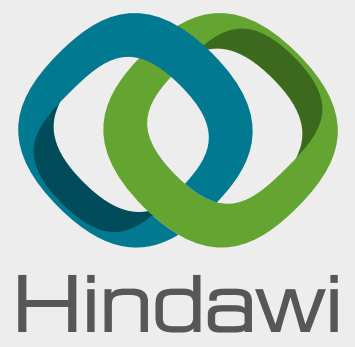

Submit your manuscripts at

www.hindawi.com
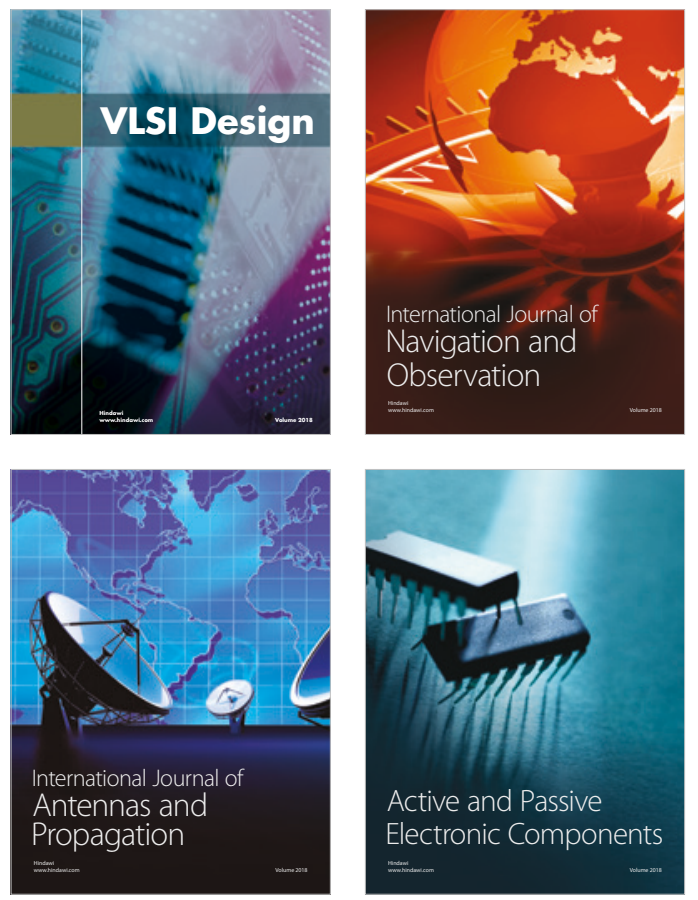
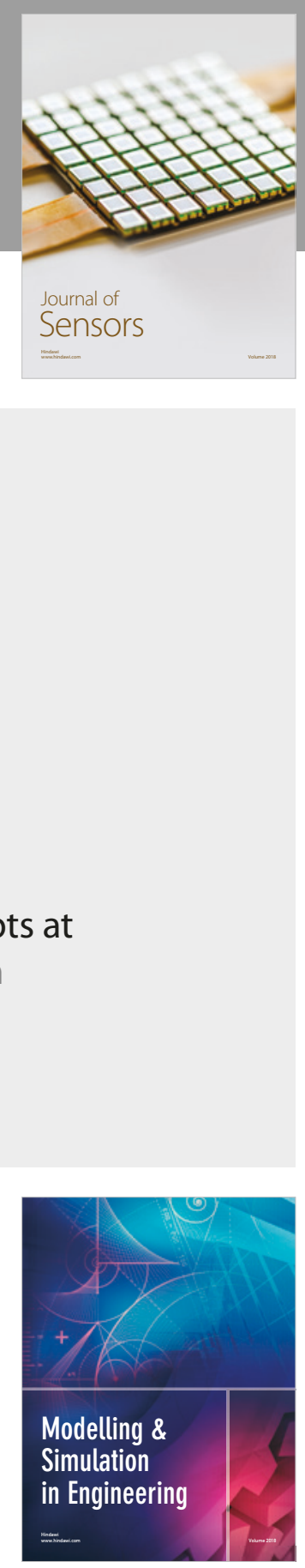

\section{Advances \\ Multimedia}
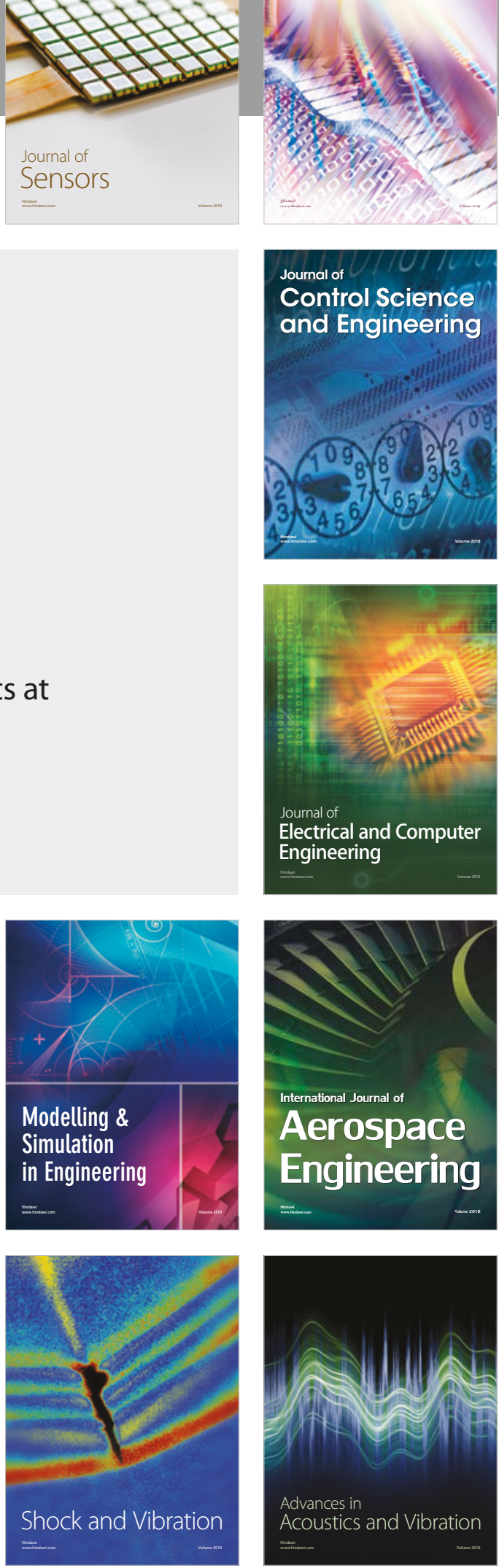